\title{
Identification of Top Performing Economies
}

\author{
Ravindra H. Dholakia* \\ and Akhilesh S. Kumar* \\ Indian Institute of Management Ahmedabad - 380015 \\ e-mail: rdholkia@iimahd.ernet.in
}

\begin{abstract}
[Using seven indicators of the economic performance of 187 countries, the paper identifies the top 50 performers during the decades of 1981-90 and 19912000. Five of these indicators are the trend rates of growth over a decade in imports, FDI, capital formation, per capita income and forex reserves. Average inflation rate and $H D I$ are the remaining indicators. Comparison of top performers of the 1980s and the 1990s suggest that high performance in inflation and HDI are the precondition for consistency of high overall performance over time. The paper also examines the interrelationship among the indicators over time.]
\end{abstract}

Key Words: Emerging Economies, Economic Indicators, Cross-Country Regression, International Ranking, and Economic Development.

\section{${ }^{*}$ Acknowledgements}

We are grateful to Prof. M.M. Monippally for going through the first draft of the paper carefully and making very useful suggestions and editorial changes. 


\section{Identification of Top Performing Economies}

\section{Introduction}

In the era of greater liberalization and globalisation, top performing economies of the world need to be carefully identified. This is important for the business strategy of existing and potential multinational corporations as well as the policy decisions of governments in different countries. Of late, several organizations have been conducting similar exercises regularly (The Economist (periodical); World Economic Forum (WEF), 1999 and 2002; International Finance Corporation (IFC), 1999; World Bank (annual) etc.). Some of these exercises use only the published macroeconomic data available readily from secondary sources (e.g. The Economist; IFC, 1999; World Bank, 2003; Global Edge, website), whereas the others combine them with specially conducted surveys in the participating countries (e.g. WEF, 1999 and 2002). Moreover, the precise objectives and focus of these exercises also differ. Some of them focus on the better performers amongst emerging markets only (e.g. The Economist, IFC, 1999;and Global Edge, website), while the others identify the most competitive and technologically advanced economies (e.g. WEF, 1999 and 2002).

The emerging economies, or more precisely, the emerging market economies, are generally identified on three criteria, viz. (i) low income or 'developing country' status, (ii) high economic growth, and (iii) government policies leading to greater opening of the economy to domestic and global market forces. (Arnold \& Quelch, 1998 and Hoskisson et al., 2000). The Economist currently identifies two distinct sets viz. emerging economies and developed countries where size is also one of the criteria (Jan. 2, 1999 issue p.17). In 1995 it had suggested grouping of countries into 'paralysed' (the poor economies), 'progressing' (the emerging economies), and 'paranoid' (the rich countries terrified by competition from the progressives). However, it soon realized that these groupings would not remain stable over time, given the ever-changing nature of the global forces, and decided to identify two sets based on the economic expansion through sound policies followed by countries with the absolute size of the economy playing an important role. IFC (1999) identified 51 rapidly growing developing countries as emerging economies and Hoskisson et al. (2000) added 13 transition economies in the former USSR to make it a list of 64 emerging market economies. All developed countries were excluded from their list. 
There is, however, no serious effort at identifying the top performing economies in the world over a period, say a decade, irrespective of the level of their development. We need to consider the economic performance of different countries on various dimensions relevant for corporate business strategies and government policies. The present paper makes an attempt in this direction by first considering a set of relevant indicators of economic performance over a decade (Section II) and then identifying the top 50 economies with the help of those indicators (Section III). We report the results of this exercise for the decades of the eighties and the nineties and examine their similarities and implications (Section IV). The paper concludes by discussing the possibility of predicting a set of top performers for the next decade.

\section{Indicators of Performance over a Decade}

Since business interests are linked to the market, we may look for the performance indicators primarily connected with the markets. We may, therefore consider the international trade of a country to get our first indicator of performance. Imports of goods and services into an economy provide the rest of the world with the market opportunities to do business with the country. While the size of imports determines the importance of the economy, its rate of growth over a fairly long period, say a decade, would reflect the performance of the economy. It is not the size but the rate of expansion that provides the business opportunity. We expect a performing economy to have a consistently high growth of imports. If a performing economy shows a low growth of imports, it implies presence of either domestic distortions or restrictive trade policies as in case of Japan (Teramishi, 1992), Malta (Bonnici, 2002), Cyprus, Panama, etc. Both represent negative aspects of the economic performance of a country. On the other hand, if the growth of imports is high on a sustained basis in a country not performing well on other fronts, e.g., Brazil, Ghana, Mexico, Turkey, etc. it may reflect a long-term strategy for growth based on the correction of domestic distortion. A period as long as a decade would hopefully ensure that short term and temporary factors do not unduly influence the results.

The second indicator could be the ability of the economy to attract foreign capital. Trade liberalization is certainly an important dimension of globalisation, but factors flowing across the border are also an integral part of the concept as accepted by the World Trade Organisation and its agreements on investment and 
services (Goyal and Mohd, 2001). Since Capital is fungible and relatively more mobile across nations, the net inflows of the foreign direct investment (FDI) during a year would again reflect the level of development of an economy. Growth in these flows over a decade would reveal changing perceptions of the global community and fundamental changes taking place in the structure and policies in the economy. Very low growth of FDI over a decade would indicate either relative stagnation \& saturation of the growth prospects of the economy in the foreigners' perception or presence of policies discouraging FDI. Both these are negative aspects of economic performance. High growth of FDI, like high growth of imports gives extra weight to the globally emerging markets.

The third criterion to identify the top performers is to consider the total capital investment or capital formation undertaken in the economy. The gross capital formation (GCF) during a year reflects the level of development of an economy. The growth of real GCF over a decade reveals the rate of acceleration in the productive capacity and thereby indicates the maximum growth the economy is capable of achieving. It is possible to argue that an economy can grow over time mainly through sustained technical progress and may not, therefore, require very high growth of $\mathrm{GCF}^{*}$. However, most of the technical advances over a long time require fresh doses of capital (Nelson, 1964). A high rate of technical progress on a sustained basis would lead to a high rate of obsolescence and hence a high rate of depreciation. The gross investment would, therefore, show high growth. Thus, a performing economy is not likely to show low growth of GCF.

The next criterion could be the size of the market as measured by the per capita purchasing power generated in the system. Per capita real gross domestic product (GDP pc) is us ually taken to reflect the level of development of a country. Its rate of growth sustained over a decade would be an undisputed indicator of economic performance of an economy. All the studies citied earlier have considered an indicator measuring economic expansion. We propose to consider GDP and not GNP because we would like to emphasize the productive capacity

\footnotetext{
*1 Solow (1957) and Abramovitz (1956) challenged the existing belief that capital accumulation played very important role in the growth of a country. Several empirical studies of the developed countries, e.g. Denison (1967) and Auer (1979) corroborated their finding that technical progress plays overwhelming role in accounting for the growth of per capita income of a country. However, recent evidences from the study of developing countries e.g. World Bank (1991) and Young (1995), show a significant share of capital accumulation in the growth of a country. The issue is far from settled empirically. Easterly and Levine (2001) consider it a stylised fact that total factor productivity growth (TFPG) or the residual is more important than the capital accumulation.
} 
and resource efficiency in a geographical region rather than income accruing to the resources of a country. Secondly, the economic performance should be measured over time after adjusting for population growth.

Another criterion for measuring the economic performance of economies is price stability. Low inflation is one of the long-term policy objectives in almost all countries. The lower the consumer price inflation, the better the investment and business climate in a country (Barro, 1997,p-89). A low average rate of inflation in a country implies that the relative prices of commodities tend to remain more or less stable. The relative demand for commodities would then be determined by the growth of income and change in tastes and preferences. Both these are reasonably predictable and therefore business uncertainties and risks are lower. High inflation, on the contrary, leads to greater business uncertainties and risks. Inflation is a distinct aspect of the economic performance of a country and should be included as a performance criterion to give due consideration to the business climate and sentiments.

Yet another performance indicator is the net result of the balance of payments of the country. The net effect of the current account and capital account is on the total reserves of foreign currency in the economy. There are several countries that have been aggressively pursuing the policy of accumulating foreign exchange reserves in their central monetary authority so that the currency crisis or any such threat to the stability of their financial system can be effectively tackled if need arises (Jalan, 2002; and Kapur and Patel, 2003). In the light of the experience of the currency and financial crises during the last decade, the behaviour of the total reserves of foreign currencies in the country assumes a special significance as an indicator of the performance of the economy. It basically acts like a signal of the market power of the country's central monetary authority in the forex market. Again, it is not the level but the growth of reserves that reflects the economic performance of the country over a decade.

Finally, we consider the performance of an economy in terms of its past developmental efforts, specific points of advantage gained through deliberate development strategy or available through natural endowments, gifts or coincidences. All these factors get converted into the development of human resources in the country. The human development index (HDI) is based on the achievements of the economy on education, health, and income. It is a reasonably comprehensive measure of the level of human development in a country in relation 
to other countries (UNDP, 2002). The level of HDI once attained is likely to sustain itself over time. Rapid improvements are possible but drastic reductions are unlikely. Since the level of HDI generally signals the quality of human resource in a country, it may also reflect the ability to generate innovations, absorb technical progress, and adapt to changing business environments. All these factors are likely to determine the potential of the country for economic growth and advancement. We, therefore, take the level of HDI prevailing in a country at the mid-point of the decade as an important indicator of economic performance over the decade.

Based on various aspects of the economic performance of a country relevant from the business angle, we have identified seven different indicators. Except HDI the other six indicators are annual rates of growth over a decade ${ }^{*}$. For consumer price inflation, an arithmetic average of the annual rate is taken over the relevant decade. For the remaining five indicators, semi-logarithmic time trend rate is estimated for the two decades. All these seven indicators are calculated for all countries $^{* 3}$ for the decades 1981-90 and 1991-2000 respectively in Appendix Tables 1 and 2.

How distinct are these seven indicators, chosen to reflect the economic performance of countries? They appear to be quite distinct and to represent different dimensions of the economic performance of countries during the 1980s and the 1990s. Tables 1 and 2 report the correlation matrices among these seven indicators for the 1980s and the 1990s respectively ${ }^{*}$. It is evident that none of the correlations is very high and substantial where $r^{2}$ exceeds 0.5 . In fact, for most of the pairs, $r^{2}$ is less than 0.1 , and for several pairs $r^{2}$ is less than 0.01 . Thus the chosen seven indicators have captured quite distinct dimensions of the economic performance of countries during the last two decades. Moreover, the two tables

\footnotetext{
*2 The imports, GCF and GDPpc are measured in constant 1995 US dollars, whereas the net inflow of FDI is in current US dollars. Time series data on these four variables along with the consumer price annual inflation rate are available from the World Development Indicators (2002). Time series on forex reserves is available from IMF (2002), and the HDI is available from the UNDP (2002).

${ }^{*}$ Out of 207 countries for which the World Development Indicators (2002) provides data, the nonavailability of data does not permit us to construct even one indicator either for the 1980s or the 1990s in the case of 20 countries. We have, therefore, dropped those 20 countries from our analysis. For two countries (Afghanistan and Libya) none of the seven indicators could be constructed for the 1990s whereas there were nine such countries for the 1980s. Moreover, countries are defined as distinct economies rather than political area. Thus, politically Macao and Hong Kong fall under China, but here we have considered them as two economies or countries.

${ }^{*} 4$ The number of observations for each correlation in these tables differs because of the nonreporting of data on different indicators in the basic sources.
} 
also show a general weakening of the correlations during the 1990s when compared with the 1980s for all indicators except inflation. This is an interesting finding because it means that the economic performance of countries, which was already specialised on a few dimensions, is becoming more specialised and focused during the 1990s when compared to the 1980s. It suggests that the development goals, targets, and strategies are becoming sharper and narrowly focused over time.

Table 1: Correlation Matrix among the Seven Indicators - 1980s

\begin{tabular}{|c|c|c|c|c|c|c|}
\hline & Ggcf & Gimpgs & Gfdi & Gfr & INF & HDI \\
\hline Ggdppc & $\begin{array}{r}0.68084 \\
(n=132)\end{array}$ & $\begin{array}{l}0.55525 \\
(n=130)\end{array}$ & $\begin{array}{l}0.16520 \\
(n=103)\end{array}$ & $\begin{array}{l}0.40805 \\
(n=134)\end{array}$ & $\begin{array}{l}0.29126 \\
(n=131)\end{array}$ & $\begin{array}{l}0.34090 \\
(n=123)\end{array}$ \\
\hline Ggcf & & $\begin{array}{l}0.62415 \\
(n=127)\end{array}$ & $\begin{array}{r}0.20253 \\
(n=95) \\
\end{array}$ & $\begin{array}{l}0.50281 \\
(n=119)\end{array}$ & $\begin{array}{l}0.13590 \\
(n=117)\end{array}$ & $\begin{array}{r}0.04504 \\
(n=111)\end{array}$ \\
\hline Gimpgs & & & $\begin{array}{r}0.12082 \\
(n=97)\end{array}$ & $\begin{array}{l}0.42460 \\
(n=123)\end{array}$ & $\begin{array}{l}0.10950 \\
(n=123)\end{array}$ & $\begin{array}{l}0.31355 \\
(n=109)\end{array}$ \\
\hline Gfdi & & & & $\begin{array}{l}0.16193 \\
(n=105)\end{array}$ & $\begin{array}{r}0.00308 \\
(n=99\end{array}$ & $\begin{array}{r}0.35334 \\
(n=87)\end{array}$ \\
\hline Gfr & & & & & $\begin{array}{l}0.10554 \\
(n=128)\end{array}$ & $\begin{array}{l}0.12514 \\
(n=109)\end{array}$ \\
\hline INF & & & & & & $\begin{array}{r}0.01486 \\
(n=108)\end{array}$ \\
\hline
\end{tabular}

Basic Source: Appendix Table 1

Table 2: Correlation Matrix among the Seven Indicators - 1990s

\begin{tabular}{|c|c|c|c|c|c|c|}
\hline & Ggcf & Gimpgs & Gfdi & Gfr & INF & HDI \\
\hline Ggdppc & $\begin{array}{c}0.53666 \\
(n=155)\end{array}$ & $\begin{array}{l}0.57737 \\
(n=158)\end{array}$ & $\begin{array}{l}0.08711 \\
(n=155)\end{array}$ & $\begin{array}{l}0.02706 \\
(n=164\end{array}$ & $\begin{array}{l}0.34676 \\
(\mathrm{n}=159)\end{array}$ & $\begin{array}{l}0.15655 \\
(n=139)\end{array}$ \\
\hline Ggcf & & $\begin{array}{l}0.61736 \\
(\mathrm{n}=153)\end{array}$ & $\begin{array}{l}0.14944 \\
(\mathrm{n}=141)\end{array}$ & $\begin{array}{l}0.04251 \\
(\mathrm{n}=151\end{array}$ & $\begin{array}{l}0.09696 \\
(\mathrm{n}=148)\end{array}$ & $\begin{array}{l}0.02863 \\
(n=130)\end{array}$ \\
\hline Gimpgs & & & $\begin{array}{l}0.08429 \\
(n=144)\end{array}$ & $\begin{array}{l}0.0168 \mathrm{a} \\
(\mathrm{n}=154\end{array}$ & $\begin{array}{l}0.28562 \\
(\mathrm{n}=151)\end{array}$ & $\begin{array}{l}0.15748 \\
(n=131)\end{array}$ \\
\hline Gfdi & & & & $\begin{array}{l}0.13572 \\
(n=151\end{array}$ & $\begin{array}{l}0.02729 \\
(\mathrm{n}=148)\end{array}$ & $\begin{array}{l}0.02901 \\
(n=132)\end{array}$ \\
\hline Gfr & & & & & $\begin{array}{l}0.01629 \\
(\mathrm{n}=160)\end{array}$ & $\begin{array}{l}0.08516 \\
(n=133)\end{array}$ \\
\hline INF & & & & & & $\begin{array}{c}0.06286 \\
(n=133)\end{array}$ \\
\hline
\end{tabular}

Basic Source: Appendix Table 2

This has an important implication for the identification of the top performers because the standard methods of "combining" different indicators attaching 'some uniform weights' become invalid and even conceptually challengeable. Thus, different popular methods like using the equal weights to ranking of individual indicators, or statistically derived weights through the principal component method (Gamini, et al., 2002; Biswas and Caliendo,2002 and Güveli, 2000), or equal weights after converting the indicators into indices as in PQLI (Morris, 1979) and 
HDI (UNDP, 2002) are all meaningless in the light of our finings. The countries have different perceptions and attach different importance to various dimensions of the economic performance. Any uniform scale of weights cannot do justice to all. We need a different approach.

\section{Identifying The Top Performers}

If the economic performance of countries is considered along one dimension and with one indicator, the rankings generally are non-controversial. However, when there are several dimensions and multiple indicators, overall rankings would be problematic. But, in order to identify a certain number of top performers, we may not need precise overall rankings of countries. This is because, if our objective is to identify the 50 top overall performers, we can first identify the top 50 countries in each of the seven indicators by awarding one point each. We would then emerge with seven different sets of 50 countries each. The countries that are common to all the seven sets are necessarily among the top 50 overall performers. This would be a sub-set comprising of only a small number of countries if at all. During the nineties, for example, there was no such country and during the eighties, there were only three such countries. We may, then, consider countries present in six out of the seven sets. These countries are among the top 50 performers in six out of the seven dimensions. Again the number of such countries is likely to be small, e.g. only eight such countries in the 1980s and two in the 1990s. We can, then, consider the countries appearing in any five sets, 4 sets and so on. Table 3 provides the distribution of 187 countries considered in this study according to their score that shows the number of sets they appear in during the 1980s and the 1990s.

Table 3: Distribution of Countries According to their Score During the 1980s and the 1990s

\begin{tabular}{|l|r|r|r|r|r|r|r|r|}
\hline Score * & 7 & 6 & 5 & 4 & 3 & 2 & 1 & 0 \\
\hline No. of Countries During the 1980s & 3 & 8 & 14 & 14 & 17 & 26 & 52 & 53 \\
\hline No. of Countries During the 1990s & 0 & 2 & 10 & 18 & 36 & 30 & 48 & 43 \\
\hline
\end{tabular}

* If a country appears in one set during the decade, it gets a score of one. The score of five, for instance, means that the country is in top 50 countries in five out of seven indicators during the decade

Source: Calculated from Appendix Tables 1 and 2 
Some interesting patterns of economic performance of countries emerge from Table 3. The number of all-round performers scoring at least five points has sharply reduced to 12 during the 1990s compared to 25 during the 1980s. But at the same time, the number of countries with a score of two or more has increased from 82 in the 1980s to 96 in the 1990s. An average country during the eighties had a score of one or none, whereas during the nineties it has two or more. However, among the top performers, the shift appears to be in the reverse direction - an average top performer having a score of four or more during the 1980 s to only three during the 1990s.

We may return to our question of how to select the top 50 overall performers if the distribution of the countries is as given in Table 3 . We can readily see that there are 39 countries in the 1980s and 30 countries in the 1990s with a score of four or more, but there are 56 countries in the 1980s and 66 countries in the 1990s with a score three or more. Therefore, we have to select 11 out of 17 countries in the 1980s and 20 out of 36 countries in the 1990s with the score of three to complete the list of 50 top overall performers in each decade. In order to select those countries, the indicators are converted into the corresponding indexes with the best value in the indicator during a decade as 100 and the worst value as zero, from among all 187 countries. This exercise is done only for those indicators where the country ranks in the top 50 . Then, the index values for all the three indicators in each of the 17 countries in the 1980s and 36 countries in the 1990s are added to arrive at the rankings of those countries so as to select 11 countries in the $1980 \mathrm{~s}$ and 20 countries in the $1990 \mathrm{~s}^{* 5}$. The top 50 overall performers so identified in the 1980s and the 1990s are presented in Tables 4 and 5 respectively along with their rankings in the seven indicators and the total score.

\footnotetext{
${ }^{*}$ Equal weights to indexes at this stage is justified because all the countries in the group have appeared in the top 50 performers in any three out of the seven indicators. Our suggested method picks up only those indicators for a country where it has performed. Different countries may have performed on different indicators. Index only measures the strength of their relative performance compared to the best and the worst performers. Equal weights to add such relative performance in three different dimensions has nothing objectionable.
} 
Table 4: Top 50 Countries on Overall Economic Performance During the 1980

\begin{tabular}{|c|c|c|c|c|c|c|c|c|c|}
\hline No. & Country & Ggdppc & Ggcf & Gimpgs & Gfdi & Gfr & INF & $\mathrm{HDI}$ & Score @ \\
\hline & & Rank & Rank & Rank & Rank & Rank & Rank & Rank & \\
\hline 1 & Japan & 27 & 29 & 25 & 21 & 33 & 7 & 4 & 7 \\
\hline 2 & Korea, Rep. & 3 & 4 & 6 & 17 & 20 & 47 & 39 & 7 \\
\hline 3 & United Kingdom & 36 & 23 & 20 & 11 & 39 & 49 & 18 & 7 \\
\hline 4 & Belize & 47 & 6 & 51 & 14 & 10 & 27 & 48 & 6 \\
\hline 5 & Canada & 60 & 34 & 19 & 13 & 25 & 43 & 1 & 6 \\
\hline 6 & Denmark & 66 & 35 & 48 & 4 & 31 & 42 & 8 & 6 \\
\hline 7 & Finland & 41 & 55 & 39 & 7 & 23 & 50 & 12 & 6 \\
\hline 8 & Spain & 40 & 24 & 12 & 29 & 22 & 75 & 20 & 6 \\
\hline 9 & St. Kitts and Nevis & 2 & 1 & 29 & 12 & 26 & 20 & & 6 \\
\hline 10 & St. Vincent and the Grenadines & 14 & 22 & $\overline{46}$ & 20 & 30 & 32 & & 6 \\
\hline 11 & Thailand & 9 & 8 & 5 & 28 & 14 & 30 & 61 & 6 \\
\hline 12 & Antigua and Barbuda & 5 & 10 & 21 & & 35 & 48 & & 5 \\
\hline 13 & Belgium & 59 & 42 & 47 & 37 & 53 & 18 & 10 & 5 \\
\hline 14 & China & 1 & 5 & 15 & 27 & 49 & 87 & 79 & 5 \\
\hline 15 & Dominica & & 26 & 36 & 5 & 17 & 34 & & 5 \\
\hline 16 & Luxembourg & 16 & 17 & 30 & & & 31 & 17 & 5 \\
\hline 17 & Malta & 22 & 12 & 16 & 71 & 90 & 9 & 33 & 5 \\
\hline 18 & Mauritius & 12 & 9 & 3 & 8 & 1 & 69 & 59 & 5 \\
\hline 19 & Portugal & 33 & 51 & 17 & 19 & 6 & 102 & 34 & 5 \\
\hline 20 & Singapore & 17 & 67 & & 49 & 44 & 8 & 36 & 5 \\
\hline 21 & St. Lucia & 8 & 16 & 11 & 77 & 19 & 28 & & 5 \\
\hline 22 & Sweden & 55 & 31 & 41 & 23 & 37 & 61 & 8 & 5 \\
\hline 23 & Switzerland & 75 & 48 & 38 & 37 & 68 & 18 & 5 & 5 \\
\hline 24 & Turkey & 38 & 27 & 10 & 25 & 29 & 121 & 67 & 5 \\
\hline 25 & United States & 44 & 54 & 18 & 44 & 51 & 35 & 2 & 5 \\
\hline 26 & Australia & 63 & 59 & 34 & 39 & 36 & 67 & 12 & 4 \\
\hline 27 & Botswana & 6 & 3 & 7 & 68 & 4 & 81 & 73 & 4 \\
\hline 28 & Chad & 31 & & 8 & 106 & 11 & 12 & 117 & 4 \\
\hline 29 & Costa Rica & 95 & 21 & 14 & 51 & 40 & 116 & 41 & 4 \\
\hline 30 & Cyprus & 13 & 56 & 54 & 79 & 46 & 36 & 26 & 4 \\
\hline 31 & France & 65 & 53 & 45 & 32 & 82 & 46 & 10 & 4 \\
\hline 32 & Grenada & 10 & 38 & 71 & 24 & 89 & 38 & & 4 \\
\hline 33 & Hong Kong, China & 11 & 50 & 2 & & & 66 & 25 & 4 \\
\hline 34 & India & 29 & 25 & 31 & 35 & 120 & 72 & 97 & 4 \\
\hline 35 & Italy & 49 & 63 & 27 & 67 & 45 & 77 & 19 & 4 \\
\hline 36 & Macao, China & 25 & 18 & 23 & & 3 & 76 & & 4 \\
\hline 37 & Mali & 137 & 46 & 24 & 50 & 18 & & 118 & 4 \\
\hline 38 & Netherlands & 67 & 52 & 49 & 33 & 73 & 11 & 6 & 4 \\
\hline 39 & Seychelles & 21 & 7 & 1 & 56 & 99 & 15 & & 4 \\
\hline 40 & Austria & 61 & 60 & 42 & 52 & 74 & 22 & 15 & 3 \\
\hline 41 & Burkina Faso & 91 & 14 & 72 & 93 & 24 & 3 & 121 & 3 \\
\hline 42 & Chile & 35 & 11 & 61 & 58 & 69 & 108 & 42 & 3 \\
\hline 43 & Dominican Republic & 90 & 33 & 4 & 47 & 123 & 114 & 65 & 3 \\
\hline 44 & Germany & 53 & 64 & 58 & 34 & 81 & 13 & 14 & 3 \\
\hline 45 & Greece & 97 & 85 & 43 & 62 & 34 & 106 & 22 & 3 \\
\hline 46 & Ireland & 37 & 89 & 35 & 94 & 61 & 64 & 21 & 3 \\
\hline 47 & New Zealand & 96 & 77 & 56 & 30 & 21 & 82 & 16 & 3 \\
\hline 48 & Norway & 50 & 82 & 74 & 36 & 55 & 63 & 6 & 3 \\
\hline 49 & Panama & 152 & 129 & 111 & 3 & 100 & 5 & 44 & 3 \\
\hline 50 & Swaziland & 24 & 69 & 50 & 16 & 57 & 96 & 85 & 3 \\
\hline
\end{tabular}

@The number of indicators in which the country is in top 50

Basic Source: (1) World Development Indicators 2002 (on CD ROM)

(2) International Financial Statistics 2003 (online: http://ifs.apdi.net)

(3) Human Development Report 2002 (online: http://hdr.undp.org) 
Table 5: Top 50 Countries on Overall Economic Performance During the 1990

\begin{tabular}{|c|c|c|c|c|c|c|c|c|c|}
\hline No. & Country & Ggdppc & Ggcf & Gimpgs & Gfdi & Gfr & INF & $\mathrm{HDI}$ & Score @ \\
\hline & & Rank & Rank & Rank & Rank & Rank & Rank & Rank & \\
\hline 1 & Ireland & 4 & 14 & 6 & 22 & 131 & 30 & 21 & 6 \\
\hline 2 & Poland & 8 & 8 & 4 & 26 & 17 & 129 & 39 & 6 \\
\hline 3 & Australia & 38 & 40 & 37 & 124 & 117 & 18 & 2 & 5 \\
\hline 4 & Croatia & 26 & 29 & 90 & 16 & 9 & 154 & 41 & 4 \\
\hline 5 & India & 18 & 24 & 27 & 27 & 23 & 87 & 102 & 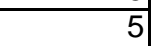 \\
\hline 6 & Korea, Rep. & 17 & 119 & 30 & 34 & 40 & 62 & 28 & 5 \\
\hline 7 & Lithuania & 159 & 22 & 48 & 9 & 10 & 145 & 43 & 5 \\
\hline 8 & Slovak Republic & 32 & 18 & 13 & 61 & 26 & 90 & 33 & 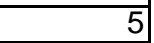 \\
\hline 9 & Trinidad and Tobago & 49 & 6 & 28 & 89 & 36 & 66 & 42 & 5 \\
\hline 10 & Uganda & 24 & 21 & 5 & 7 & 15 & 105 & 125 & 5 \\
\hline 11 & United States & 53 & 26 & 26 & 35 & 145 & 32 & $4 \mid$ & 5 \\
\hline 12 & Vietnam & 5 & 5 & 2 & 86 & 29 & 45 & 88 & 5 \\
\hline 13 & Bangladesh & 36 & 23 & 22 & 4 & 150 & 63 & 116 & 4 \\
\hline 14 & Canada & 66 & 55 & 47 & 40 & 84 & 13 & 1 & 4 \\
\hline 15 & Chile & 9 & 30 & 23 & 57 & 92 & 94 & 37 & 4 \\
\hline 16 & \begin{tabular}{|l|} 
Denmark \\
\end{tabular} & 67 & 47 & 73 & 39 & 87 & 15 & 16 & 4 \\
\hline 17 & Finland & 31 & 77 & 51 & 19 & 124 & 10 & 15 & 4 \\
\hline 18 & Hungary & 44 & 12 & 9 & 134 & 80 & 117 & 38 & 4 \\
\hline 19 & Israel & 68 & 94 & 44 & 48 & 39 & 96 & 22 & 4 \\
\hline 20 & \begin{tabular}{|l|} 
Japan \\
\end{tabular} & 104 & 124 & 94 & 38 & 46 & 2 & 7 & 4 \\
\hline 21 & Luxembourg & 20 & 45 & 83 & & 155 & 16 & 13 & 4 \\
\hline 22 & Maldives & 7 & 39 & 32 & 118 & 24 & 78 & 72 & 4 \\
\hline 23 & Malta & 25 & 127 & 119 & 42 & 135 & 34 & 30 & 4 \\
\hline 24 & New Zealand & 73 & 32 & 49 & 138 & 125 & 8 & 18 & 4 \\
\hline 25 & Nicaragua & 103 & 9 & 19 & 23 & 35 & 156 & 95 & 4 \\
\hline 26 & Romania & 120 & 143 & 38 & 15 & 48 & 151 & 48 & 4 \\
\hline 27 & Singapore & 13 & 38 & & 117 & 89 & 7 & 26 & 4 \\
\hline 28 & Slovenia & 27 & 10 & 53 & 116 & 11 & 107 & 28 & 4 \\
\hline 29 & Uruguay & 56 & 71 & 41 & 14 & 43 & 139 & 35 & 4 \\
\hline 30 & Yemen, Rep. & 42 & 19 & 46 & & 22 & 132 & 119 & 4 \\
\hline 31 & Armenia & 127 & 42 & 159 & 8 & 5 & 160 & 70 & \\
\hline 32 & Austria & 84 & 103 & 72 & 49 & 116 & 21 & 14 & \\
\hline 33 & Bahamas, The & 115 & & & 5 & 83 & 28 & 34 & \\
\hline 34 & Belgium & 78 & 93 & 95 & 44 & 148 & 11 & 2 & 3 \\
\hline 35 & Bosnia and Herzen. & 2 & 3 & 3 & & & & & \\
\hline 36 & Cyprus & 33 & 140 & 135 & 132 & 119 & 47 & 25 & \\
\hline 37 & Czech Republic & 86 & 44 & 7 & 54 & 66 & 79 & 31 & 3 \\
\hline 38 & Equatorial Guinea & 1 & 2 & 1 & 74 & 100 & & 98 & 3 \\
\hline 39 & Georgia & 178 & 1 & 17 & 6 & 163 & 140 & & 3 \\
\hline 40 & Germany & 100 & 113 & 85 & 12 & 151 & 19 & 16 & 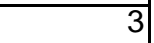 \\
\hline 41 & Malaysia & 22 & 90 & 39 & 151 & 96 & 44 & 53 & 3 \\
\hline 42 & Netherlands & 62 & 89 & 80 & 47 & 161 & 26 & 8 & 5 \\
\hline 43 & Norway & 37 & 54 & 76 & 59 & 112 & 24 & 4 & 3 \\
\hline 44 & Panama & 80 & 20 & 100 & 53 & 102 & 5 & 50 & 3 \\
\hline 45 & Seychelles & 108 & 36 & 8 & 82 & 140 & 20 & & 4 \\
\hline 46 & Spain & 52 & 86 & 33 & 126 & 157 & 49 & 20 & 3 \\
\hline 47 & Sudan & 6 & & & 1 & 13 & 148 & 112 & 3 \\
\hline 48 & Sweden & 72 & 88 & 60 & 36 & 159 & 23 & 4 & 3 \\
\hline 49 & Switzerland & 117 & 110 & 91 & 44 & 137 & 11 & 11 & 3 \\
\hline 50 & United Kingdom & 54 & 65 & 57 & 50 & 144 & 35 & 10 & 3 \\
\hline
\end{tabular}

@The number of indicators in which the country is in top 50

Basic Source: (1) World Development Indicators 2002 (on CD ROM)

(2) International Financial Statistics 2003 (online: http://ifs.apdi.net)

(3) Human Development Report 2002 (online: http://hdr.undp.org) 
The advantage of this method over the other methods is that non-availability of data on one, two or three indicators for a country does not disqualify the country from being effectively considered. Actually, Tables 4 and 5 clearly bring out that there are several countries among the top 50 performing economies in the world, where the data on some of the seven indicators are not available or reported. Methodological requirements of comprehensive data availability should not come in the way of recognizing their superior performance on other fronts. The only assumption we have to make about the non-availability of an indicator value in a country is that the country does not rank among the top 50 in that particular indicator during the decade. It is certainly not as restrictive an assumption or a procedure as dropping the country altogether from the analysis, a common practice in other similar exercises.

\section{Top Performers of the 1980s and the 1990s}

A comparison of the top 50 performers during the 1980s and the 1990s is interesting. Twenty-six countries are common to both the lists. Twenty-four countries out of the top 50 during the 1980s dropped out of the list to make room for 24 new entrants during the 1990s. Out of the 24 emerging top performers during the 1990s, as many as 13 countries had serious problems about data availability during the 1980s. It is difficult to say whether they would have made it into the top 50 performers in the 1980s had satisfactory data been available on all indicators during the 1980s. Ignoring the problem of data availability, however, it is important to compare the performance of all these 74 countries over two decades. Table 6 provides the comparison in terms of the seven indicators between the two decades for each of the 26 countries common to both the lists. 
Table 6: Comparison of Performance of the Common 26 Countries during 1980s and 1990s

\begin{tabular}{|c|c|c|c|c|c|c|c|c|c|}
\hline No. & Nations & GDP pc & GCF & Imp GS & FDI & TR & INF & HDI & Score \\
\hline \multirow{2}{*}{$\rightarrow$} & Australia $80 \mathrm{~s}$ & 0.0216 & 0.0346 & 0.0576 & 0.1965 & 0.1312 & 8.1277 & 0.873 & 4 \\
\hline & $90 \mathrm{~s}$ & 0.0300 & 0.0701 & 0.0842 & 0.0675 & 0.0515 & 2.2212 & 0.927 & 5 \\
\hline \multirow[t]{2}{*}{2} & Austria & 0.0221 & 0.0331 & 0.0506 & 0.1265 & 0.0395 & 3.5296 & 0.867 & 3 \\
\hline & $90 \mathrm{~s}$ & 0.0172 & 0.0207 & 0.0584 & 0.2592 & 0.0532 & 2.3185 & 0.909 & 3 \\
\hline \multirow[t]{2}{*}{3} & Belgium & 0.0225 & 0.0495 & 0.0482 & 0.2032 & 0.0755 & 3.4088 & 0.875 & 5 \\
\hline & $90 \mathrm{~s}$ & 0.0187 & 0.0308 & 0.0452 & 0.2734 & -0.0069 & 1.9597 & 0.927 & 3 \\
\hline \multirow[t]{2}{*}{ |4 } & Canada & 0.0222 & 0.0560 & 0.0785 & 0.3591 & 0.1681 & 5.9693 & 0.906 & 6 \\
\hline & $90 \mathrm{~s}$ & 0.0223 & 0.0566 & 0.0778 & 0.2923 & 0.1043 & 1.9968 & 0.932 & 4 \\
\hline \multirow[t]{2}{*}{5} & Chile & 0.0321 & 0.0907 & 0.0357 & 0.0942 & 0.0447 & 20.4466 & 0.754 & 3 \\
\hline & $90 \mathrm{~s}$ & 0.0477 & 0.0803 & 0.0999 & 0.2398 & 0.0844 & 9.5399 & 0.811 & 4 \\
\hline \multirow[t]{2}{*}{6} & Cyprus & 0.0529 & 0.0386 & 0.0442 & 0.0207 & 0.0932 & 4.8960 & 0.821 & 4 \\
\hline & $90 \mathrm{~s}$ & 0.0316 & -0.0321 & 0.0019 & 0.0333 & 0.0501 & 3.8301 & 0.866 & 3 \\
\hline \multirow[t]{2}{*}{7} & Denmark 80s & 0.0204 & 0.0552 & 0.0479 & 0.5453 & 0.1407 & 5.9457 & 0.883 & 6 \\
\hline & $90 \mathrm{~s}$ & 0.0221 & 0.0615 & 0.0579 & 0.2942 & 0.1013 & 2.1377 & 0.907 & 4 \\
\hline \multirow[t]{2}{*}{8} & Finland & 0.0295 & 0.0387 & 0.0519 & 0.4559 & 0.1784 & 6.7690 & 0.873 & 6 \\
\hline & $90 \mathrm{~s}$ & 0.0324 & 0.0414 & 0.0737 & 0.3746 & 0.0414 & 1.8628 & 0.908 & 4 \\
\hline \multirow[t]{2}{*}{9} & Germany & 0.0237 & 0.0284 & 0.0387 & 0.2234 & 0.0245 & 2.6323 & 0.868 & 3 \\
\hline & $90 \mathrm{~s}$ & 0.0118 & 0.0132 & 0.0519 & 0.4441 & -0.0153 & 2.2454 & 0.907 & 3 \\
\hline \multirow[t]{2}{*}{10} & India & 0.0354 & 0.0653 & 0.0599 & 0.2109 & -0.0821 & 8.8793 & 0.473 & 4 \\
\hline & $90 \mathrm{~s}$ & 0.0431 & 0.0831 & 0.0959 & 0.3470 & 0.2310 & 9.0508 & 0.545 & 5 \\
\hline \multirow[t]{2}{*}{11} & Ireland & 0.0315 & -0.0063 & 0.0574 & -0.1125 & 0.0553 & 7.8471 & 0.846 & 3 \\
\hline & $90 \mathrm{~s}$ & 0.0684 & 0.1079 & 0.1358 & 0.3568 & 0.0351 & 2.5392 & 0.894 & 6 \\
\hline \multirow[t]{2}{*}{12} & Japan & 0.0360 & 0.0601 & 0.0654 & 0.2997 & 0.1382 & 2.0582 & 0.893 & 7 \\
\hline & $90 \mathrm{~s}$ & 0.0101 & -0.0007 & 0.0453 & 0.2978 & 0.1852 & 0.8345 & 0.923 & 4 \\
\hline \multirow[t]{2}{*}{13} & Korea, Rep.80s & 0.0761 & 0.1200 & 0.1126 & 0.3467 & 0.1871 & 6.3942 & 0.774 & 7 \\
\hline & $90 \mathrm{~s}$ & 0.0433 & 0.0041 & 0.0904 & 0.3124 & 0.1990 & 5.0970 & 0.852 & 5 \\
\hline \multirow[t]{2}{*}{14} & Luxembourg 80s & 0.0481 & 0.0733 & 0.0622 & & & 4.4578 & 0.860 & 5 \\
\hline & $90 \mathrm{~s}$ & 0.0396 & 0.0631 & 0.0523 & & -0.0207 & 2.1842 & 0.912 & 4 \\
\hline \multirow[t]{2}{*}{15} & Malta & 0.0397 & 0.0870 & 0.0816 & 0.0580 & 0.0044 & 2.2998 & 0.793 & 5 \\
\hline & $90 \mathrm{~s}$ & 0.0381 & -0.0032 & 0.0200 & 0.2839 & 0.0275 & 2.8937 & 0.850 & 4 \\
\hline \multirow[t]{2}{*}{16} & Netherlands $80 \mathrm{~s}$ & 0.0203 & 0.0412 & 0.0478 & 0.2324 & 0.0397 & 2.4606 & 0.888 & 4 \\
\hline & $90 \mathrm{~s}$ & 0.0231 & 0.0324 & 0.0531 & 0.2679 & -0.0757 & 2.4517 & 0.922 & 3 \\
\hline \multirow[t]{2}{*}{17} & New Zealand 80s & 0.0067 & 0.0148 & 0.0427 & 0.2378 & 0.1869 & 10.8799 & 0.866 & 3 \\
\hline & $90 \mathrm{~s}$ & 0.0194 & 0.0774 & 0.0749 & 0.0099 & 0.0405 & 1.7520 & 0.902 & 4 \\
\hline \multirow[t]{2}{*}{18} & Norway & 0.0244 & 0.0056 & 0.0268 & 0.2068 & 0.0727 & 7.6645 & 0.888 & 3 \\
\hline & $90 \mathrm{~s}$ & 0.0302 & 0.0569 & 0.0555 & 0.2343 & 0.0547 & 2.3404 & 0.925 & 3 \\
\hline 19 & Panama & -0.0215 & -0.0989 & -0.0230 & 0.5903 & -0.0159 & 1.8440 & 0.745 & 3 \\
\hline & $90 \mathrm{~s}$ & 0.0186 & 0.0963 & 0.0401 & 0.2442 & 0.0707 & 1.1682 & 0.770 & 3 \\
\hline 20 & Seychelles 80s & 0.0410 & 0.0980 & 0.1480 & 0.1144 & -0.0141 & 3.0784 & & 4 \\
\hline & $90 \mathrm{~s}$ & 0.0085 & 0.0719 & 0.1239 & 0.1780 & 0.0108 & 2.2870 & & 3 \\
\hline 21 & Singapore 80s & 0.0471 & 0.0237 & & 0.1437 & 0.1002 & 2.2843 & 0.782 & 5 \\
\hline & $90 \mathrm{~s}$ & 0.0445 & 0.0714 & & 0.0824 & 0.0981 & 1.7296 & 0.857 & 4 \\
\hline 22 & Spain & 0.0298 & 0.0674 & 0.0949 & 0.2457 & 0.1844 & 9.3628 & 0.855 & 6 \\
\hline & $90 \mathrm{~s}$ & 0.0251 & 0.0336 & 0.0894 & 0.0645 & -0.0265 & 3.8929 & 0.895 & 3 \\
\hline 23 & Sweden & 0.0233 & 0.0589 & 0.0512 & 0.2809 & 0.1287 & 7.6141 & 0.883 & 5 \\
\hline & $90 \mathrm{~s}$ & 0.0195 & 0.0324 & 0.0678 & 0.2996 & -0.0467 & 2.3303 & 0.925 & 3 \\
\hline 24 & Switzerland 80s & 0.0162 & 0.0447 & 0.0535 & 0.2032 & 0.0456 & 3.4088 & 0.892 & 5 \\
\hline & $90 \mathrm{~s}$ & 0.0043 & 0.0154 & 0.0467 & 0.2734 & 0.0221 & 1.9597 & 0.914 & 3 \\
\hline 25 & United Kingdom 80s & 0.0318 & 0.0678 & 0.0681 & 0.3807 & 0.1227 & 6.5854 & 0.858 & 7 \\
\hline & $90 \mathrm{~s}$ & 0.0241 & 0.0501 & 0.0705 & 0.2550 & -0.0008 & 3.0520 & 0.916 & 3 \\
\hline 26 & United States $80 \mathrm{~s}$ & 0.0275 & 0.0399 & 0.0790 & 0.1786 & 0.0797 & 4.7401 & 0.898 & 5 \\
\hline & $90 \mathrm{~s}$ & 0.0243 & 0.0818 & 0.0974 & 0.3080 & -0.0009 & 2.8014 & 0.925 & 5 \\
\hline
\end{tabular}

Basic Source: Appendix Table 1 and 2 
The table clearly reveals that in only five countries, viz., Australia, Chile, India, Ireland and New Zealand, has the country score increased during the 1990s over the 1980s. In another five countries, it has remained the same and in the remaining 16 countries, it has fallen. Thus, although the 26 countries appear to have maintained their status as belonging to the top 50 performers in the $1980 \mathrm{~s}$ and the 1990s, in 16 of them the relative performance has actually deteriorated over the years. A closer look at Table 6 reveals that, while the absolute performance in terms of most of the seven indicators has deteriorated for several of these 16 countries, it has actually improved for Denmark, Finland, and the Netherlands in spite of their relative performance going down. The trend rate of growth of per capita real GDP has increased from the 1980s to the 1990s only in nine out of these 26 common top performers during the two decades.

Another distinctive feature of the 26 common countries coming out clearly from Table 6 is that except India, all countries have very high performance on the inflation and / or HDI front. Among this group of consistent performers, India is the only country with poor performance on both these counts. Except India, all countries show improvement in terms of inflation, while on the HDI front, all countries show clear improvement. It appears that high level of human development with good control over consumer inflation is almost a pre-condition for consistently high overall economic performance ${ }^{*}$. None of the other five indicators generates such a close association.

Those 24 countries that dropped out of the list of 50 top performers during the 1990s from the list of the 1980s tell a story of all-round deteriorated performance except HDI (Table 7). In HDI, there is a clear improvement in all countries.

\footnotetext{
${ }^{*}$ See Barro (1997), Ch. 3. Using similar measurement and concept of consumer inflation with the cross-country data for the 1960,1970s and 1980s, he finds a significant negative relation between inflation and growth. He also finds the "causation from higher long-term inflation to reduced growth" (p.117). Barro's (1997) results do provide support to our finding here. It should be noted, however, that our finding considers good relative performance of a country on multiple dimensions and not on a single dimension of growth in income.
} 
Table 7: Comparison of Performance of 24 Countries Not Listed among the Top Performers during 1990s

\begin{tabular}{|c|c|c|c|c|c|c|c|c|c|}
\hline No. & Nations & GDP pc & GCF & Imp GS & FDI & TR & INF & $\mathrm{HDI}$ & Score \\
\hline \multirow[t]{2}{*}{1} & Antigua and Barbuda 80s & 0.0657 & 0.0925 & 0.0680 & & 0.1332 & 6.4708 & & 5 \\
\hline & 90s & 0.0286 & 0.0207 & 0.0300 & & 0.0704 & 2.5180 & & 2 \\
\hline \multirow[t]{2}{*}{2} & Belize & 0.0263 & 0.0988 & 0.0453 & 0.3583 & 0.2356 & 4.1761 & 0.718 & 6 \\
\hline & $90 \mathrm{~s}$ & 0.0139 & 0.0304 & 0.0270 & 0.0739 & 0.0810 & 1.7580 & 0.772 & 2 \\
\hline \multirow[t]{2}{*}{3} & Botswana & 0.0637 & 0.1293 & 0.1100 & 0.0616 & 0.2925 & 10.5841 & 0.613 & 4 \\
\hline & $90 \mathrm{~s}$ & 0.0234 & -0.0046 & 0.0147 & -0.1791 & 0.0728 & 10.5134 & 0.620 & 0 \\
\hline \multirow[t]{2}{*}{4} & Burkina Faso & 0.0092 & 0.0800 & 0.0280 & -0.0983 & 0.1703 & 1.3416 & 0.282 & 3 \\
\hline & $90 \mathrm{~s}$ & 0.0230 & 0.0749 & 0.0182 & -0.0250 & -0.0012 & 4.5795 & 0.300 & 1 \\
\hline \multirow[t]{2}{*}{5} & Chad & 0.0341 & & 0.1087 & -0.2529 & 0.2346 & 2.5345 & 0.298 & 4 \\
\hline & $90 \mathrm{~s}$ & -0.0089 & & -0.0368 & 0.1503 & 0.1104 & 7.0622 & 0.335 & 0 \\
\hline \multirow[t]{2}{*}{6} & China & 0.0823 & 0.1072 & 0.0928 & 0.2599 & 0.0829 & 11.8369 & 0.591 & 5 \\
\hline & $90 s$ & 0.0856 & 0.1067 & 0.0530 & 0.1911 & 0.2411 & 7.4735 & 0.681 & 3 \\
\hline \multirow[t]{2}{*}{7} & Costa Rica & 0.0070 & 0.0707 & 0.0928 & 0.1266 & 0.1180 & 27.1867 & 0.770 & 4 \\
\hline & $90 \mathrm{~s}$ & 0.0298 & 0.0468 & 0.0865 & 0.1261 & 0.0478 & 16.0461 & 0.805 & 3 \\
\hline \multirow[t]{2}{*}{8} & Dominica & & 0.0628 & 0.0554 & 0.5195 & 0.1911 & 4.6900 & & 5 \\
\hline & $90 \mathrm{~s}$ & & 0.0162 & 0.0166 & -0.0540 & 0.0701 & 2.1072 & & 1 \\
\hline \multirow[t]{2}{*}{9} & Dominican Republic 80s & 0.0092 & 0.0564 & 0.1230 & 0.1580 & -0.0892 & 24.2451 & 0.667 & 3 \\
\hline & $90 \mathrm{~s}$ & 0.0444 & 0.0639 & 0.0677 & 0.2316 & 0.0384 & 11.0107 & 0.698 & 2 \\
\hline \multirow[t]{2}{*}{10} & France & 0.0205 & 0.0406 & 0.0497 & 0.2343 & 0.0242 & 6.3683 & 0.875 & 4 \\
\hline & $90 s$ & 0.0146 & 0.0191 & 0.0563 & 0.1064 & 0.0511 & 1.7242 & 0.914 & 2 \\
\hline \multirow[t]{2}{*}{11} & Greece & 0.0064 & 0.0010 & 0.0504 & 0.0876 & 0.1378 & 19.0408 & 0.845 & 3 \\
\hline & $90 s$ & 0.0192 & 0.0373 & 0.0638 & -0.0182 & 0.1350 & 9.3896 & 0.868 & 1 \\
\hline \multirow[t]{2}{*}{12} & Grenada & 0.0571 & 0.0512 & 0.0289 & 0.2772 & 0.0072 & 5.2858 & & 4 \\
\hline & $90 s$ & 0.0326 & 0.0533 & 0.0652 & 0.1113 & 0.1534 & 2.1959 & & 2 \\
\hline \multirow[t]{2}{*}{13} & Hong Kong, China 80s & 0.0549 & 0.0423 & 0.1340 & & & 8.0906 & 0.823 & 4 \\
\hline & $90 \mathrm{~s}$ & 0.0159 & 0.0454 & 0.0709 & & 0.1552 & 5.3448 & 0.877 & 1 \\
\hline \multirow[t]{2}{*}{14} & Italy & 0.0257 & 0.0287 & 0.0645 & 0.0660 & 0.0950 & 9.7217 & 0.856 & 4 \\
\hline & $90 s$ & 0.0146 & 0.0181 & 0.0497 & 0.1239 & -0.0188 & 3.7292 & 0.897 & 2 \\
\hline \multirow[t]{2}{*}{15} & Macao, China & 0.0372 & 0.0722 & 0.0668 & & 0.3159 & 9.6485 & & 4 \\
\hline & $90 \mathrm{~s}$ & -0.0030 & -0.0692 & 0.0094 & & 0.1461 & 3.3975 & & 1 \\
\hline \multirow[t]{2}{*}{16} & Mali & -0.0132 & 0.0453 & 0.0668 & 0.1420 & 0.1907 & & 0.292 & 4 \\
\hline & $90 \mathrm{~s}$ & 0.0147 & -0.0045 & 0.0287 & 0.1758 & 0.0403 & 4.0512 & 0.346 & 0 \\
\hline \multirow[t]{2}{*}{17} & Mauritius & 0.0535 & 0.0942 & 0.1310 & 0.4555 & 0.3921 & 8.3024 & 0.686 & 5 \\
\hline & 90s & 0.0399 & 0.0392 & 0.0522 & 0.2164 & -0.0089 & 6.6819 & 0.746 & 1 \\
\hline \multirow[t]{2}{*}{18} & Portugal & 0.0337 & 0.0414 & 0.0800 & 0.3240 & 0.2584 & 17.3141 & 0.787 & 5 \\
\hline & $90 \mathrm{~s}$ & 0.0262 & 0.0549 & 0.0727 & 0.0649 & -0.0663 & 4.9396 & 0.855 & 2 \\
\hline \multirow[t]{2}{*}{19} & St. Kitts and Nevis & 0.0765 & 0.1377 & 0.0626 & 0.3604 & 0.1600 & 3.4399 & & 6 \\
\hline & $90 \mathrm{~s}$ & 0.0467 & 0.0460 & 0.0457 & 0.1800 & 0.1038 & 3.5251 & & 2 \\
\hline \multirow[t]{2}{*}{20} & St. Lucia & 0.0596 & 0.0742 & 0.0972 & 0.0272 & 0.1885 & 4.2976 & & 5 \\
\hline & $90 s$ & 0.0076 & 0.0246 & 0.0018 & 0.0519 & 0.0500 & 3.2908 & & 1 \\
\hline 21 & St. Vincent and Gren. 80s & 0.0523 & 0.0688 & 0.0490 & 0.3102 & 0.1445 & 4.5265 & & 6 \\
\hline & $90 \mathrm{~s}$ & 0.0275 & 0.0511 & 0.0301 & 0.1640 & 0.0712 & 2.4217 & & 2 \\
\hline 22 & Swaziland & 0.0385 & 0.0227 & 0.0469 & 0.3516 & 0.0693 & 14.5265 & 0.569 & 3 \\
\hline & $90 \mathrm{~s}$ & 0.0023 & 0.0209 & 0.0268 & -0.2400 & 0.0616 & 9.4532 & 0.620 & 0 \\
\hline 23 & Thailand & 0.0594 & 0.0979 & 0.1222 & 0.2462 & 0.2044 & 4.4398 & 0.676 & 6 \\
\hline & $90 \mathrm{~s}$ & 0.0267 & -0.0627 & 0.0309 & 0.1360 & 0.0636 & 4.5367 & 0.749 & 1 \\
\hline 24 & Turkey & 0.0300 & 0.0617 & 0.0984 & 0.2769 & 0.1467 & 46.2873 & 0.654 & 5 \\
\hline & $90 s$ & 0.0215 & 0.0426 & 0.1124 & 0.0230 & 0.1928 & 76.7014 & 0.717 & 2 \\
\hline
\end{tabular}

Basic Source: Appendix Table 1 and 2 
Table 7 shows that in 18 out of 24 countries, the trend rate of growth in per capita real GDP has fallen sharply during the 1990s compared to the 1980s. The presence of China among these 24 countries is somewhat surprising because it has experienced absolute improvement in all but two indicators and yet it has lost its place relative to the others. However, drawing from our earlier discussion, we can argue that China is not performing very well relatively on both HDI and inflation and hence may not be able to maintain consistently high overall economic performance. In fact, out of the performers of the eighties there are only two countries, viz., France and Belize that have high performance on HDI and inflation and yet failed to maintain consistently high relative overall economic performance during the 1990s.

The group of the emerging performers of the 1990s is presented in Table 8. Non-availability of data for the 1980s in the case of 11 out of the 24 countries makes it difficult to draw meaningful conclusions. Some of those countries could have been among the top 50 countries had the satisfactory data been available for the 1980s. From whatever data are available, however, we can say that several of these new entrants to this club of 50 are relatively shaky in the sense that they may not be able to hold on to their membership in the coming decade. This is because their performance on $\mathrm{HDI}$ and inflation front is relatively not high and far from what is required. Thus Armenia, Bangladesh, Bosnia, Equatorial Guinea, Georgia, Maldives, Nicaragua, Sudan, Uganda, and Yemen will have to be extra cautious and make extra efforts to maintain their relative performance over the next decade. 
Table 8: Comparison of Performance of 24 Countries Emerging only in 1990s as Top Performers

\begin{tabular}{|c|c|c|c|c|c|c|c|c|c|c|}
\hline No. & Nations & & GDP pc & GCF & Imp GS & FDI & TR & INF & $\mathrm{HDI}$ & Score \\
\hline \multirow[t]{2}{*}{1} & Armenia & $80 \mathrm{~s}$ & & & & & & & & 0 \\
\hline & $90 \mathrm{~s}$ & & 0.0018 & 0.0656 & -0.1179 & 0.5094 & 0.6214 & 739.9026 & 0.715 & 3 \\
\hline \multirow[t]{2}{*}{2} & Bahamas, Tr & e $80 s$ & 0.0244 & & & & 0.0153 & 5.5348 & 0.817 & 2 \\
\hline & $90 \mathrm{~s}$ & & 0.0055 & & & 0.6045 & 0.1086 & 2.5162 & 0.816 & 3 \\
\hline \multirow[t]{2}{*}{3} & Bangladesh & $80 s$ & 0.0145 & 0.0192 & 0.0646 & -0.2326 & 0.1274 & 7.3649 & 0.386 & 2 \\
\hline & $90 \mathrm{~s}$ & & 0.0304 & 0.0933 & 0.1034 & 0.6091 & -0.0122 & 5.2992 & 0.445 & 4 \\
\hline \multirow[t]{2}{*}{4} & Bosnia and $\mathrm{H}$ & erzegovina 80 s & & & & & & & & 0 \\
\hline & $90 \mathrm{~s}$ & & 0.1840 & 0.3047 & 0.1960 & & & & & 3 \\
\hline \multirow[t]{2}{*}{5} & Croatia & $80 s$ & & & & & & 453.8095 & & 0 \\
\hline & $90 \mathrm{~s}$ & & 0.0376 & 0.0805 & 0.0473 & 0.3964 & 0.3176 & 238.2516 & 0.789 & 5 \\
\hline \multirow[t]{2}{*}{6} & Czech Repu & lic $80 \mathrm{~s}$ & & & & & & & & 0 \\
\hline & $90 \mathrm{~s}$ & & 0.0164 & 0.0638 & 0.1331 & 0.2409 & 0.1479 & 7.5935 & 0.843 & 3 \\
\hline \multirow[t]{2}{*}{7} & Equatorial G & inea 80s & -0.0087 & & 0.0580 & & -0.0421 & & 0.533 & 1 \\
\hline & $90 \mathrm{~s}$ & & 0.1948 & 0.3841 & 0.4202 & 0.1978 & 0.0727 & & 0.582 & 3 \\
\hline \multirow[t]{2}{*}{8} & Georgia & $80 \mathrm{~s}$ & -0.0090 & & & & & & & 0 \\
\hline & $90 \mathrm{~s}$ & & -0.0966 & 0.4818 & 0.1059 & 0.5642 & -0.1046 & 39.3309 & & 3 \\
\hline \multirow[t]{2}{*}{9} & Hungary & $80 \mathrm{~s}$ & 0.0158 & -0.0059 & 0.0192 & & -0.0966 & 10.9270 & 0.805 & 1 \\
\hline & $90 \mathrm{~s}$ & & 0.0284 & 0.1133 & 0.1167 & 0.0234 & 0.1141 & 20.2521 & 0.809 & 4 \\
\hline \multirow[t]{2}{*}{10} & Israel & $80 \mathrm{~s}$ & 0.0174 & 0.0223 & 0.0405 & 0.1225 & 0.0277 & 118.2897 & 0.836 & 1 \\
\hline & $90 \mathrm{~s}$ & & 0.0219 & 0.0307 & 0.0795 & 0.2624 & 0.2007 & 9.6304 & 0.877 & 4 \\
\hline \multirow[t]{2}{*}{11} & Lithuania & $80 s$ & 0.0629 & & & & & & & 1 \\
\hline & $90 \mathrm{~s}$ & & -0.0153 & 0.0946 & 0.0752 & 0.4751 & 0.3169 & 70.3021 & 0.781 & 5 \\
\hline \multirow[t]{2}{*}{12} & Malaysia & $80 s$ & 0.0229 & 0.0235 & 0.0679 & 0.0102 & 0.0738 & 3.2481 & 0.693 & 2 \\
\hline & $90 \mathrm{~s}$ & & 0.0391 & 0.0321 & 0.0831 & -0.1203 & 0.0793 & 3.5538 & 0.760 & 3 \\
\hline \multirow[t]{2}{*}{13} & Maldives & $80 \mathrm{~s}$ & 0.0706 & & & 0.0063 & 0.2372 & & 0.629 & 2 \\
\hline & $90 \mathrm{~s}$ & & 0.0568 & 0.0704 & 0.0895 & 0.0799 & 0.2296 & 7.4807 & 0.707 & 4 \\
\hline \multirow[t]{2}{*}{14} & Nicaragua & $80 s$ & -0.0515 & -0.0745 & -0.0270 & & & 2438.8706 & 0.584 & 0 \\
\hline & $90 \mathrm{~s}$ & & 0.0106 & 0.1192 & 0.1053 & 0.3554 & 0.2097 & 339.1007 & 0.615 & 4 \\
\hline \multirow[t]{2}{*}{15} & Poland & $80 \mathrm{~s}$ & -0.0736 & & & 0.0600 & 0.2022 & 107.6725 & & 1 \\
\hline & $90 \mathrm{~s}$ & & 0.0506 & 0.1252 & 0.1450 & 0.3483 & 0.2749 & 28.4287 & 0.808 & 6 \\
\hline \multirow[t]{2}{*}{\begin{tabular}{|l|}
16 \\
\end{tabular}} & Romania & $80 \mathrm{~s}$ & -0.0027 & 0.0712 & -0.0052 & & 0.0479 & 22.2534 & 0.794 & 2 \\
\hline & $90 \mathrm{~s}$ & & 0.0034 & -0.0388 & 0.0835 & 0.4008 & 0.1840 & 121.0157 & 0.772 & 4 \\
\hline \multirow[t]{2}{*}{17} & Slovak Repu & lic $80 \mathrm{~s}$ & 0.0154 & 0.0028 & 0.0360 & & & & 0.813 & 1 \\
\hline & $90 \mathrm{~s}$ & & 0.0317 & 0.0999 & 0.1113 & 0.2333 & 0.2231 & 9.2172 & 0.817 & 5 \\
\hline \multirow[t]{2}{*}{18} & Slovenia & $80 \mathrm{~s}$ & & & & & & & & 0 \\
\hline & $90 \mathrm{~s}$ & & 0.0363 & 0.1146 & 0.0734 & 0.0888 & 0.3141 & 13.6422 & 0.852 & 4 \\
\hline \multirow[t]{2}{*}{19} & Sudan & $80 \mathrm{~s}$ & -0.0245 & & & & -0.0727 & 40.2020 & 0.395 & 0 \\
\hline & $90 \mathrm{~s}$ & & 0.0571 & & & 1.5106 & 0.3072 & 82.1034 & 0.462 & 3 \\
\hline 20 & Trinidad and & Tobago 80s & -0.0256 & -0.1122 & 0.0217 & 0.4437 & -0.3699 & 11.0800 & 0.774 & 2 \\
\hline & $90 \mathrm{~s}$ & & 0.0264 & 0.1368 & 0.0952 & 0.1602 & 0.2096 & 5.4693 & 0.787 & 5 \\
\hline 21 & Uganda & $80 s$ & 0.0037 & 0.0770 & 0.0430 & & -0.1121 & 103.4137 & 0.386 & 1 \\
\hline & $90 \mathrm{~s}$ & & 0.0387 & 0.0958 & 0.1403 & 0.5299 & 0.2992 & 12.8222 & 0.404 & 5 \\
\hline 22 & Uruguay & $80 s$ & 0.0054 & -0.0495 & 0.0131 & 0.1175 & 0.0639 & 62.4875 & 0.781 & 1 \\
\hline & $90 \mathrm{~s}$ & & 0.0238 & 0.0450 & 0.0820 & 0.4198 & 0.1914 & 38.0910 & 0.815 & 4 \\
\hline 23 & Vietnam & $80 \mathrm{~s}$ & 0.0219 & & & & & & 0.583 & 0 \\
\hline & $90 \mathrm{~s}$ & & 0.0590 & 0.1737 & 0.2688 & 0.1679 & 0.2170 & 3.7115 & 0.649 & 5 \\
\hline 24 & Yemen, Rep & $80 \mathrm{~s}$ & & & & -0.5380 & & & & 0 \\
\hline & $90 \mathrm{~s}$ & & 0.0287 & 0.0999 & 0.0783 & & 0.2385 & 30.6111 & 0.439 & 4 \\
\hline
\end{tabular}

Basic Source: Appendix Table 1 and 2 
The key to success in these economies appears to be control of inflation because they are lagging far behind in terms of HDI, the other critical indicator. Malaysia, The Bahamas, and Trinidad and Tobago, on the other hand, are very likely to maintain their relative performance during the next decade. All other countries on the list have to tackle the problem of high inflation in their economy to achieve stability and consistency of performance. It is in-deed surprising that all the emerging performers of the 1990s except The Bahamas, Malaysia, and Vietnam have experienced relatively very high average inflation rate during the 1990 s. Thus, high inflation during a decade does not deter the solid real economic performance on the other dimensions during the same decade, ${ }^{*} 7$ but may create problems of maintaining the consistency of relative performance over time, if not checked.

\section{Predicting Future Performance}

Finally, we attempt to predict the economic performance of countries in the next decade. As a first step, we find the correlation for each indicator value during the 1980s and the 1990s. All correlation coefficients are very low except for HDI where it turns out to be $+0.9853^{*}{ }^{8}$. For the rest, the $r^{2} s$ are less than 0.09 . Thus, except HDI, the future values of the other six indicators are not highly correlated with their current values when performance over a decade is considered on a given dimension. As a second step, then, we take the past performance on all the seven dimensions to check whether the future performance on seven individual dimensions can be explained. We, therefore, run regressions with each indicator in the 1990s as the dependent variable and all the seven indicators in the 1980s as the independent variables ${ }^{*}$. Here our intension is to examine the explanatory power of the performance indicator we are using rather than statistically mining explanatory variables. Four of our seven indicators are not explained satisfactorily

\footnotetext{
${ }^{*}$ Our finding here appears to be in sharp contrast to Barro (1997) who finds "no sign in any range of a positive relation that would signify that higher inflation had to be tolerated to obtain more growth" (p.98). While growth of income is just one dimension of economic performance, we are considering multiple dimensions and only the emerging performers during the nineties.

${ }^{*} 8$ This is not surprising since HDI is more of a stock variable.

*9 Here the problem of data non-availability becomes a severe constraint. Fitting a multiple regression requires that the data matrix be complete and uniform for all variables. When we consider this constraint, the number of countries falls sharply from 187 to only 80 . Since 80 is a large sample, our result may be considered reliable for prediction if found statistically significant.
} 
by the past performance measures. Only three out of the seven regressions turn out to be statistically significant at $3 \%$ level of significance in terms of the goodness of fit test. On these three regressions, we applied the step-wise regression procedures to arrive at the most significant and acceptable fit. The results are as under:

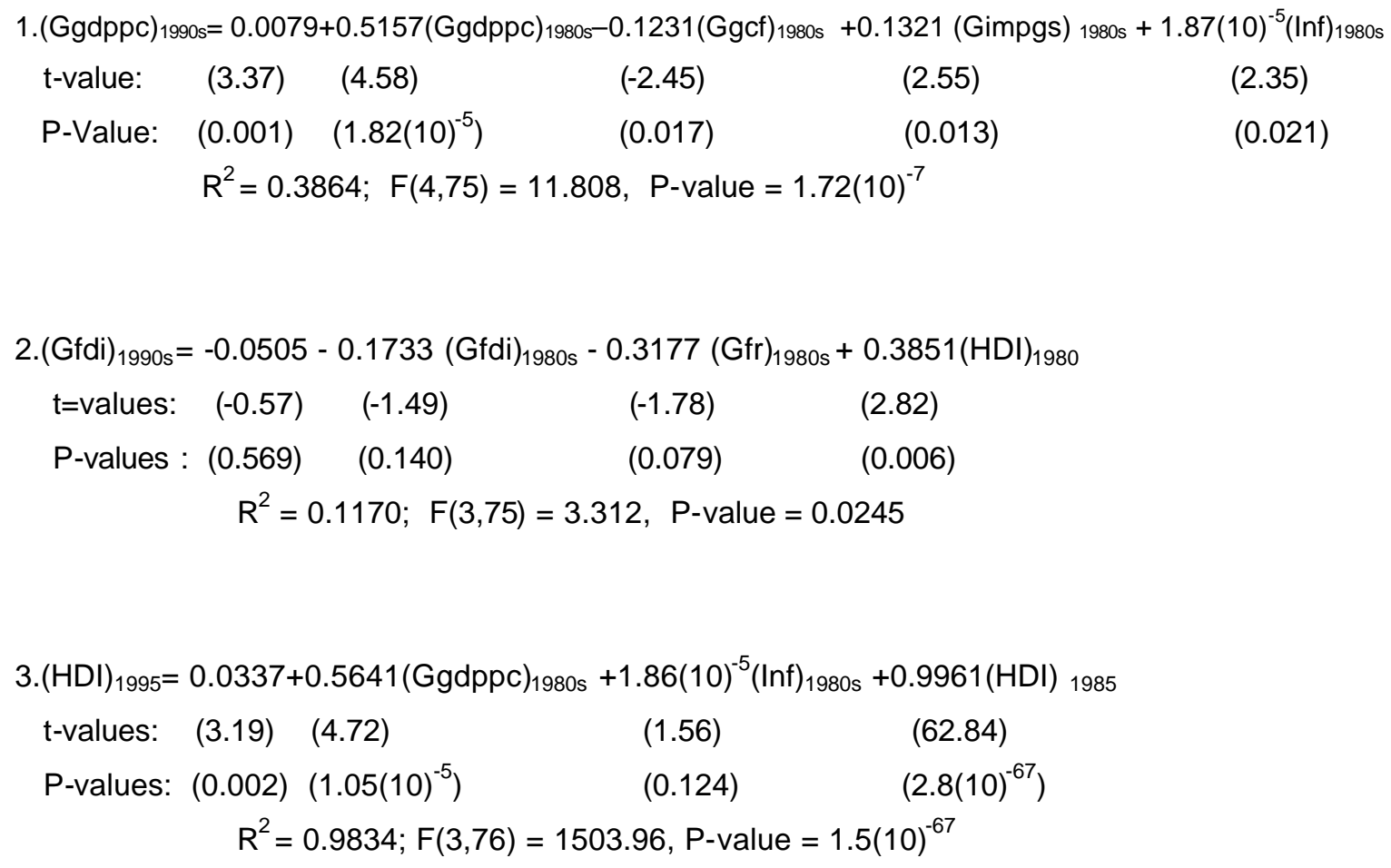

These findings do spring some surprises:

1. Contrary to what Barro (1997) found, inflation in our equation (1) has a positive and significant coefficient implying a direct relationship with growth of income. Thus, our finding suggests the existence of a trade-off between higher inflation and higher growth.

2. A negative and significant coefficient of Ggcf in equation (1) seems to contradict the finding of Blomstrom et al. (1996) that investment does not cause future growth. Higher investment is likely to result in higher incremental capital-output ratio by depressing the rate of return ultimately leading to a fall in the future growth of income. Thus, investment may cause output growth, albeit negatively. 
3. A negative and significant coefficient of Gfr in equation (2) contradicts the arguments of Patel and Kapur (2003) that the foreign investors may see high accumulation of forex reserves by a country as reducing the risk of financial crises. On the contrary, the foreign investors may perceive very rapid growth of forex reserves in a country as a symptom and a potential threat of the government intervention to the market forces.

4. In view of the importance of inflation and HDI emerging from the discussion in the previous section, the finding in equation (3) suggest some distant trade-off considering the magnitude and significance of its coefficient.

The rest of the findings of our regressions are in line with the existing literature. Thus, a positive and significant coefficient of Ggdppc in equation (3) and absence of HDI in equation (1) supports the hypothesis that growth causes human capital and not vice-versa (Bils \& Klenow, 1996). Similarly, HDI is very important for growth of FDI (equation 2).

Based on these three regressions, it is possible to generate the expected performance of different countries on the three indicators. On the assumption that the extent of relationship given by the estimated parameters in these regressions remain stable over time, we may plug in the values of the independent variables for the 1990s to generate the prediction of the trend rates of growth of per capita real GDP, and net inflow of FDI for the decade of 2001-2010, and the level of HDI in 2005 in different countries. Since the data availability is better in the 1990s, the number of countries covered in our prediction is 156 . 
Table 9: Predicted Values of 3 Performance Indicators with Ranking for the Decade 2001-10

\begin{tabular}{|c|c|c|c|c|c|c|c|c|c|c|}
\hline No. & Countries & Trend $\mathrm{G}$ & rowth in $\mathrm{G}$ & $\overline{\mathrm{DPpc}}$ & Trend & Growth in $F$ & FDI & & $\mathrm{HDI}$ & \\
\hline & & Observed & Predicted & Rank & Observed & Predicted & Rank & Observed & Predicted & Rank \\
\hline & & $1990 \mathrm{~s}$ & $2000 s$ & $2000 \mathrm{~s}$ & 1990s & $2000 \mathrm{~s}$ & $2000 \mathrm{~s}$ & 1995 & 2005 & 2005 \\
\hline 1 & Albania & 0.0438 & 0.0210 & 64 & 0.1021 & 0.1600 & 61 & 0.702 & 0.759 & 70 \\
\hline 2 & Algeria & 0.0028 & 0.0094 & 114 & -0.0846 & 0.1494 & 67 & 0.663 & 0.696 & 84 \\
\hline 3 & Antigua and Barbuda & 0.0286 & 0.0241 & 49 & & & & & & \\
\hline 4 & Argentina & 0.0224 & 0.0277 & 31 & 0.2042 & 0.1865 & 48 & 0.830 & 0.874 & 32 \\
\hline 5 & Armenia & 0.0018 & -0.0010 & 135 & 0.5094 & -0.0608 & 122 & 0.715 & 0.761 & 66 \\
\hline 6 & Australia & 0.0300 & 0.0259 & 40 & 0.0675 & 0.2785 & 77 & 0.927 & 0.974 & 2 \\
\hline 7 & Austria & 0.0172 & 0.0219 & 59 & 0.2592 & 0.2378 & 20 & 0.909 & 0.949 & 16 \\
\hline 8 & Azerbaijan & -0.0583 & -0.0129 & 142 & 0.6045 & 0.1245 & 76 & 0.816 & 0.850 & 39 \\
\hline 9 & Bahrain & 0.0090 & 0.0147 & 97 & & & & & & \\
\hline 10 & Bangladesh & 0.0304 & 0.0258 & 42 & 0.6091 & 0.0192 & 113 & 0.445 & 0.494 & 110 \\
\hline 11 & Barbados & 0.0233 & 0.0167 & 85 & & & & & & \\
\hline 12 & Belarus & -0.0060 & 0.0166 & 86 & 0.4670 & 0.1202 & 80 & 0.776 & 0.815 & 43 \\
\hline 13 & Belgium & 0.0187 & 0.0197 & 74 & 0.2734 & 0.2613 & 11 & 0.927 & 0.968 & 5 \\
\hline 14 & Belize & 0.0139 & 0.0149 & 95 & 0.0739 & 0.2083 & 36 & 0.772 & 0.811 & 47 \\
\hline 15 & Benin & 0.0191 & 0.0140 & 103 & 0.2342 & 0.0406 & 106 & 0.388 & 0.431 & 122 \\
\hline 16 & Bhutan & 0.0359 & 0.0158 & 89 & & & & & & \\
\hline 17 & Bolivia & 0.0155 & 0.0132 & 106 & 0.3402 & 0.0658 & 101 & 0.630 & 0.670 & 87 \\
\hline 18 & Botswana & 0.0234 & 0.0226 & 57 & -0.1791 & 0.1962 & 40 & 0.620 & 0.665 & 89 \\
\hline 19 & Brazil & 0.0159 & 0.0373 & 9 & 0.4325 & 0.1213 & 78 & 0.737 & 0.787 & 56 \\
\hline 20 & Bulgaria & -0.0104 & 0.0153 & 92 & 0.3910 & 0.1108 & 87 & 0.778 & 0.806 & 49 \\
\hline 21 & Burkina Faso & 0.0230 & 0.0130 & 107 & -0.0250 & 0.0698 & 98 & 0.300 & 0.346 & 131 \\
\hline 22 & Burundi & -0.0503 & -0.0156 & 143 & & & & 0.316 & 0.320 & 132 \\
\hline 23 & Cam bodia & 0.0177 & 0.0146 & 98 & 0.1619 & 0.0128 & 115 & 0.531 & 0.573 & 100 \\
\hline 24 & Cameroon & -0.0003 & 0.0138 & 104 & 0.2289 & 0.2365 & 21 & 0.499 & 0.531 & 104 \\
\hline 25 & Canada & 0.0223 & 0.0227 & 56 & 0.2923 & 0.2247 & 24 & 0.932 & 0.975 & 1 \\
\hline 26 & Cape Verde & 0.0348 & 0.0399 & 7 & 0.3292 & 0.1976 & 38 & 0.678 & 0.729 & 78 \\
\hline 27 & Central African Republic & & & & 0.1286 & 0.0233 & 112 & 0.369 & 0.401 & 124 \\
\hline 28 & Chad & & & & 0.1503 & 0.0174 & 114 & 0.335 & 0.363 & 127 \\
\hline 29 & Chile & 0.0477 & 0.0360 & 11 & 0.2398 & 0.1935 & 43 & 0.811 & 0.869 & 33 \\
\hline 30 & China & 0.0856 & 0.0460 & 3 & 0.1911 & 0.1021 & 90 & 0.681 & 0.761 & 67 \\
\hline 31 & Colombia & 0.0089 & 0.0216 & 61 & 0.1840 & 0.1965 & 39 & 0.750 & 0.786 & 57 \\
\hline 32 & Comoros & & & & 0.3654 & 0.0443 & 104 & & & \\
\hline 33 & Congo, Dem. Rep. & -0.0763 & 0.0434 & 4 & -0.0836 & 0.1873 & 47 & 0.511 & 0.589 & 99 \\
\hline 34 & Congo, Rep. & -0.0361 & -0.0029 & 136 & & & & & & \\
\hline 35 & Costa Rica & 0.0298 & 0.0292 & 25 & 0.1261 & 0.2225 & 25 & 0.805 & 0.853 & 38 \\
\hline 36 & Cote d'Ivoire & 0.0078 & 0.0048 & 125 & 0.1263 & -0.1217 & 125 & 0.416 & 0.453 & 119 \\
\hline 37 & Croatia & 0.0376 & 0.0280 & 29 & 0.3964 & 0.0838 & 93 & 0.789 & 0.845 & 40 \\
\hline 38 & Cyprus & 0.0316 & 0.0285 & 27 & 0.0333 & 0.2614 & 10 & 0.866 & 0.914 & 24 \\
\hline 39 & Czech Republic & 0.0164 & 0.0262 & 36 & 0.2409 & 0.1855 & 49 & 0.843 & 0.883 & 31 \\
\hline 40 & Denmark & 0.0221 & 0.0194 & 75 & 0.2942 & 0.2157 & 32 & 0.907 & 0.950 & 15 \\
\hline 41 & Dominican Republic & 0.0444 & 0.0320 & 18 & 0.2316 & 0.1660 & 56 & 0.698 & 0.754 & 72 \\
\hline 42 & Ecuador & -0.0058 & 0.0074 & 119 & 0.1587 & 0.1854 & 50 & 0.719 & 0.747 & 73 \\
\hline 43 & Egypt, Arab Rep. & 0.0277 & 0.0166 & 87 & 0.1400 & 0.1318 & 73 & 0.605 & 0.652 & 93 \\
\hline 44 & El Salvador & 0.0237 & 0.0273 & 33 & 0.1864 & 0.1111 & 86 & 0.682 & 0.727 & 80 \\
\hline 45 & Estonia & 0.0260 & 0.0327 & 16 & & & & & & \\
\hline 46 & Equatorial Guinea & & & & 0.1978 & 0.1163 & 82 & & & \\
\hline 47 & Ethiopia & 0.0300 & 0.0198 & 70 & 0.3905 & -0.0385 & 121 & 0.308 & 0.358 & 129 \\
\hline 48 & Fiji & 0.0063 & 0.0144 & 99 & 0.0113 & 0.2152 & 33 & 0.743 & 0.777 & 59 \\
\hline 49 & Finland & 0.0324 & 0.0292 & 24 & 0.3746 & 0.2212 & 26 & 0.908 & 0.957 & 13 \\
\hline 50 & France & 0.0146 & 0.0205 & 65 & 0.1064 & 0.2668 & 9 & 0.914 & 0.952 & 14 \\
\hline 51 & Gabon & 0.0008 & 0.0048 & 124 & & & & & & \\
\hline 52 & Gambia, The & -0.0009 & 0.0043 & 129 & 0.0718 & 0.0703 & 97 & 0.375 & 0.407 & 123 \\
\hline 53 & Georgia & -0.0966 & -0.0865 & 145 & & & & & & \\
\hline 54 & Germany & 0.0118 & 0.0192 & 76 & 0.4441 & 0.2267 & 23 & 0.907 & 0.944 & 18 \\
\hline 55 & Ghana & 0.0187 & 0.0298 & 23 & 0.0931 & 0.0964 & 92 & 0.525 & 0.568 & 101 \\
\hline 56 & Greece & 0.0192 & 0.0218 & 60 & -0.0182 & 0.2441 & 18 & 0.868 & 0.909 & 26 \\
\hline 57 & Grenada & 0.0326 & 0.0268 & 35 & & & & & & \\
\hline 58 & Guatemala & 0.0143 & 0.0203 & 66 & 0.1235 & 0.1356 & 71 & 0.609 & 0.649 & 94 \\
\hline
\end{tabular}


Table 9: Predicted Values of 3 Performance Indicators with Ranking for the Decade 2001-10 (contd.)

\begin{tabular}{|c|c|c|c|c|c|c|c|c|c|c|}
\hline No. & Countries & \multicolumn{3}{|c|}{ Trend Growth in GDPpc } & \multicolumn{3}{|c|}{ Trend Growth in FDI } & \multicolumn{3}{|c|}{$\mathrm{HDI}$} \\
\hline & & Observed & Predicted & Rank & Observed & Predicted & Rank & Observed & Predicted & Rank \\
\hline & & 1990s & $2000 s$ & $2000 s$ & 1990s & $2000 s$ & $2000 s$ & 1995 & 2005 & 2005 \\
\hline 59 & Guinea-Bissau & -0.0147 & 0.0177 & 82 & & & & 0.331 & 0.356 & 130 \\
\hline 60 & Guyana & 0.0458 & 0.0365 & 10 & -0.1037 & 0.2131 & 34 & 0.703 & 0.760 & 68 \\
\hline 61 & Haiti & -0.0234 & 0.0101 & 113 & 0.2800 & -0.0119 & 118 & 0.457 & 0.476 & 113 \\
\hline 62 & Honduras & 0.0025 & 0.0068 & 121 & 0.2264 & 0.0543 & 103 & 0.628 & 0.661 & 90 \\
\hline 63 & Hong Kong, China & 0.0159 & 0.0199 & 68 & & & & 0.877 & 0.916 & 23 \\
\hline 64 & Hungary & 0.0284 & 0.0244 & 46 & 0.0234 & 0.2208 & 28 & 0.809 & 0.856 & 37 \\
\hline 65 & Iceland & 0.0224 & 0.0212 & 63 & 0.0380 & 0.2953 & 1 & 0.918 & 0.961 & 10 \\
\hline 66 & India & 0.0431 & 0.0327 & 15 & 0.3470 & 0.0259 & 111 & 0.545 & 0.601 & 97 \\
\hline 67 & Indonesia & 0.0184 & 0.0257 & 43 & 0.2400 & 0.1210 & 79 & 0.664 & 0.706 & 83 \\
\hline 68 & Iran, Islamic Rep. & 0.0154 & -0.0041 & 138 & & & & 0.688 & 0.728 & 79 \\
\hline 69 & Ireland & 0.0684 & 0.0478 & 2 & 0.3568 & 0.2208 & 27 & 0.894 & 0.963 & 9 \\
\hline 70 & Israel & 0.0219 & 0.0261 & 39 & 0.2624 & 0.1780 & 52 & 0.877 & 0.920 & 22 \\
\hline 71 & Italy & 0.0146 & 0.0198 & 73 & 0.1239 & 0.2795 & 6 & 0.897 & 0.936 & 21 \\
\hline 72 & Jamaica & -0.0082 & 0.0048 & 126 & 0.1791 & 0.1478 & 68 & 0.736 & 0.763 & 64 \\
\hline 73 & Japan & 0.0101 & 0.0192 & 77 & 0.2978 & 0.1945 & 41 & 0.923 & 0.959 & 12 \\
\hline 74 & Jordan & 0.0107 & 0.0178 & 81 & 0.8473 & 0.0301 & 109 & 0.703 & 0.740 & 75 \\
\hline 75 & Kazakhstan & -0.0226 & 0.0040 & 130 & & & & & & \\
\hline 76 & Kenya & -0.0033 & 0.0102 & 111 & 0.2123 & 0.0323 & 108 & 0.523 & 0.553 & 102 \\
\hline 77 & Korea, Rep. & 0.0433 & 0.0417 & 5 & 0.3124 & 0.1603 & 60 & 0.852 & 0.907 & 27 \\
\hline 78 & Kuwait & -0.0143 & 0.0047 & 127 & 0.0237 & 0.2455 & 17 & 0.812 & 0.835 & 41 \\
\hline 79 & Kyrgyz Republic & -0.0399 & -0.0196 & 144 & & & & & & \\
\hline 80 & Lao PDR & & & & & & & 0.445 & 0.500 & 108 \\
\hline 81 & Latvia & -0.0007 & 0.0151 & 93 & 0.3131 & 0.1767 & 53 & 0.763 & 0.794 & 53 \\
\hline 82 & Lebanon & & & & 0.6098 & 0.0692 & 99 & & & \\
\hline 83 & Lesotho & 0.0206 & 0.0187 & 79 & 0.4556 & 0.0406 & 105 & 0.572 & 0.615 & 95 \\
\hline 84 & Lithuania & -0.0153 & -0.0004 & 133 & 0.4751 & 0.0673 & 100 & 0.781 & 0.804 & 50 \\
\hline 85 & Luxembourg & 0.0396 & 0.0275 & 32 & & & & 0.912 & 0.965 & 8 \\
\hline 86 & Macao, China & -0.0030 & 0.0161 & 88 & & & & & & \\
\hline 87 & Macedonia, FYR & -0.0076 & 0.0149 & 96 & & & & & & \\
\hline 88 & Madagascar & -0.0045 & 0.0075 & 117 & 0.1597 & 0.0259 & 110 & 0.441 & 0.471 & 114 \\
\hline 89 & Malawi & 0.0186 & 0.0283 & 28 & 0.2516 & 0.0025 & 116 & 0.403 & 0.446 & 120 \\
\hline 90 & Malaysia & 0.0391 & 0.0351 & 12 & -0.1203 & 0.2378 & 19 & 0.760 & 0.813 & 45 \\
\hline 91 & Maldives & 0.0568 & 0.0405 & 6 & 0.0799 & 0.1350 & 72 & 0.707 & 0.770 & 62 \\
\hline 92 & Mali & 0.0147 & 0.0199 & 69 & 0.1758 & 0.0395 & 107 & 0.346 & 0.387 & 125 \\
\hline 93 & Malta & 0.0381 & 0.0306 & 21 & 0.2839 & 0.2189 & 29 & 0.850 & 0.902 & 29 \\
\hline 94 & Mauritania & 0.0128 & 0.0044 & 128 & -0.1631 & 0.0713 & 96 & 0.418 & 0.457 & 117 \\
\hline 95 & Mauritius & 0.0399 & 0.0306 & 20 & 0.2164 & 0.2021 & 37 & 0.746 & 0.799 & 51 \\
\hline 96 & Mexico & 0.0147 & 0.0256 & 44 & 0.1298 & 0.1929 & 44 & 0.774 & 0.813 & 44 \\
\hline 97 & Moldova & & & & 0.3184 & 0.1674 & 55 & 0.704 & 0.688 & 85 \\
\hline 98 & Mongolia & & & & 0.2995 & 0.0741 & 95 & 0.636 & 0.673 & 86 \\
\hline 99 & Morocco & 0.0061 & 0.0157 & 90 & -0.6060 & 0.2565 & 13 & 0.569 & 0.604 & 96 \\
\hline 100 & Mozambique & 0.0441 & 0.0243 & 47 & 0.2851 & -0.0325 & 120 & 0.313 & 0.371 & 126 \\
\hline 101 & Myanmar & 0.0473 & 0.0140 & 101 & & & & & & \\
\hline 102 & Namibia & 0.0167 & 0.0156 & 91 & & & & 0.629 & 0.670 & 88 \\
\hline 103 & Nepal & 0.0233 & 0.0233 & 52 & 0.0951 & 0.0819 & 94 & 0.453 & 0.498 & 109 \\
\hline 104 & Netherlands & 0.0231 & 0.0229 & 55 & 0.2679 & 0.2822 & 5 & 0.922 & 0.965 & 7 \\
\hline 105 & New Zealand & 0.0194 & 0.0183 & 80 & 0.0099 & 0.2823 & 4 & 0.902 & 0.943 & 19 \\
\hline 106 & Nicaragua & 0.0106 & 0.0189 & 78 & 0.3554 & 0.0582 & 102 & 0.615 & 0.659 & 91 \\
\hline 107 & Niger & -0.0070 & -0.0036 & 137 & 0.0893 & 0.1069 & 88 & 0.262 & 0.291 & 133 \\
\hline 108 & Nigeria & -0.0048 & 0.0051 & 123 & 0.0182 & 0.1149 & 83 & 0.448 & 0.478 & 112 \\
\hline 109 & Norway & 0.0302 & 0.0238 & 50 & 0.2343 & 0.2478 & 15 & 0.925 & 0.972 & 3 \\
\hline 110 & Pakistan & 0.0099 & 0.0140 & 102 & 0.0515 & 0.1055 & 89 & 0.473 & 0.511 & 106 \\
\hline 111 & Panama & 0.0186 & 0.0110 & 108 & 0.2442 & 0.1813 & 51 & 0.770 & 0.811 & 46 \\
\hline 112 & Papua New Guinea & 0.0038 & 0.0133 & 105 & 0.0465 & 0.1302 & 74 & 0.519 & 0.553 & 103 \\
\hline 113 & Paraguay & -0.0050 & 0.0073 & 120 & 0.0427 & 0.2180 & 31 & 0.735 & 0.763 & 63 \\
\hline 114 & Peru & 0.0295 & 0.0262 & 37 & 0.1444 & 0.1553 & 64 & 0.730 & 0.779 & 58 \\
\hline 115 & Philippines & 0.0136 & 0.0202 & 67 & 0.1249 & 0.1614 & 58 & 0.733 & 0.772 & 61 \\
\hline
\end{tabular}


Table 9: Predicted Values of 3 Performance Indicators with Ranking for the Decade 2001-10 (concl.)

\begin{tabular}{|c|c|c|c|c|c|c|c|c|c|c|}
\hline \multirow[t]{2}{*}{ No. } & \multirow[t]{2}{*}{ Countries } & \multicolumn{3}{|c|}{ Trend Growth in GDPpc } & \multicolumn{3}{|c|}{ Trend Growth in FDI } & \multicolumn{3}{|c|}{$\mathrm{HDI}$} \\
\hline & & Observed & Predicted & Rank & Observed & Predictec & Rank & Observed & Predictec & Rank \\
\hline & & 1990s & $2000 s$ & $2000 \mathrm{~s}$ & 1990s & $2000 \mathrm{~s}$ & $2000 \mathrm{~s}$ & 1995 & 2005 & 2005 \\
\hline 116 & Poland & 0.0506 & 0.0382 & 8 & 0.3483 & 0.1130 & 84 & 0.808 & 0.868 & 34 \\
\hline 117 & Portugal & 0.0262 & 0.0243 & 48 & 0.0649 & 0.2886 & 3 & 0.855 & 0.900 & 30 \\
\hline 118 & Romania & 0.0034 & 0.0277 & 30 & 0.4008 & 0.1189 & 81 & 0.772 & 0.807 & 48 \\
\hline 119 & Russian Federation & -0.0392 & 0.0101 & 112 & 0.1944 & 0.1683 & 54 & 0.779 & 0.791 & 55 \\
\hline 120 & Rwanda & -0.0126 & -0.0006 & 134 & 0.2695 & -0.0148 & 119 & 0.335 & 0.360 & 128 \\
\hline 121 & Samoa & & & & -0.0552 & 0.2188 & 30 & 0.689 & 0.733 & 76 \\
\hline 122 & Saudi Arabia & -0.0154 & -0.0067 & 141 & & & & 0.737 & 0.759 & 69 \\
\hline 123 & Senegal & 0.0126 & 0.0106 & 109 & 0.2400 & -0.1127 & 124 & 0.400 & 0.439 & 121 \\
\hline 124 & Seychelles & 0.0085 & 0.0198 & 71 & & & & & & \\
\hline 125 & Sierra Leone & -0.0656 & 0.0036 & 131 & & & & & & \\
\hline 126 & Singapore & & & & 0.0824 & 0.2341 & 22 & 0.857 & 0.913 & 25 \\
\hline 127 & Slovak Republic & 0.0317 & 0.0268 & 34 & 0.2333 & 0.1529 & 65 & 0.817 & 0.866 & 35 \\
\hline 128 & Slovenia & 0.0363 & 0.0224 & 58 & 0.0888 & 0.1625 & 57 & 0.852 & 0.903 & 28 \\
\hline 129 & South Africa & 0.0030 & 0.0149 & 94 & 0.1003 & 0.1427 & 69 & 0.724 & 0.757 & 71 \\
\hline 130 & Spain & 0.0251 & 0.0286 & 26 & 0.0645 & 0.2915 & 2 & 0.895 & 0.939 & 20 \\
\hline 131 & Sri Lanka & 0.0387 & 0.0312 & 19 & 0.1068 & 0.1892 & 46 & 0.719 & 0.772 & 60 \\
\hline 132 & St. Kitts and Nevis & 0.0467 & 0.0324 & 17 & & & & & & \\
\hline 133 & St. Lucia & 0.0076 & 0.0090 & 115 & & & & & & \\
\hline 134 & St. Vincent and Gren. & 0.0275 & 0.0198 & 72 & & & & & & \\
\hline 135 & Sudan & & & & 1.5106 & -0.2319 & 126 & 0.462 & 0.528 & 105 \\
\hline 136 & Swaziland & 0.0023 & 0.0102 & 110 & -0.2400 & 0.2103 & 35 & 0.620 & 0.653 & 92 \\
\hline 137 & Sweden & 0.0195 & 0.0229 & 54 & 0.2996 & 0.2687 & 8 & 0.925 & 0.966 & 6 \\
\hline 138 & Switzerland & 0.0043 & 0.0144 & 100 & 0.2734 & 0.2471 & 16 & 0.914 & 0.947 & 17 \\
\hline 139 & Syrian Arab Republic & 0.0240 & 0.0170 & 84 & & & & 0.665 & 0.710 & 82 \\
\hline 140 & Tanzania & 0.0033 & 0.0074 & 118 & 0.3418 & -0.0009 & 117 & 0.427 & 0.461 & 115 \\
\hline 141 & Thailand & 0.0267 & 0.0335 & 14 & 0.1360 & 0.1942 & 42 & 0.749 & 0.795 & 52 \\
\hline 142 & Togo & 0.0012 & 0.0080 & 116 & 0.1261 & 0.1499 & 66 & 0.476 & 0.509 & 107 \\
\hline 143 & Trinidad and Tobago & 0.0264 & 0.0173 & 83 & 0.1602 & 0.1583 & 63 & 0.787 & 0.833 & 42 \\
\hline 144 & Tunisia & 0.0305 & 0.0245 & 45 & 0.0795 & 0.1597 & 62 & 0.682 & 0.730 & 77 \\
\hline 145 & Turkey & 0.0215 & 0.0300 & 22 & 0.0230 & 0.1604 & 59 & 0.717 & 0.762 & 65 \\
\hline 146 & Uganda & 0.0387 & 0.0348 & 13 & 0.5299 & -0.0818 & 123 & 0.404 & 0.458 & 116 \\
\hline 147 & Ukraine & -0.0864 & 0.0026 & 132 & 0.1983 & 0.1416 & 70 & 0.745 & 0.743 & 74 \\
\hline 148 & United Kingdom & 0.0241 & 0.0235 & 51 & 0.2550 & 0.2584 & 12 & 0.916 & 0.960 & 11 \\
\hline 149 & United States & 0.0243 & 0.0232 & 53 & 0.3080 & 0.2527 & 14 & 0.925 & 0.969 & 4 \\
\hline 150 & Uruguay & 0.0238 & 0.0261 & 38 & 0.4198 & 0.1298 & 75 & 0.815 & 0.860 & 36 \\
\hline 151 & Vanuatu & -0.0143 & -0.0063 & 140 & & & & & & \\
\hline 152 & Venezuela, RB & -0.0106 & 0.0067 & 122 & 0.2315 & 0.1895 & 45 & 0.766 & 0.791 & 54 \\
\hline 153 & Vietnam & 0.0590 & 0.0525 & 1 & 0.1679 & 0.1014 & 91 & 0.649 & 0.714 & 81 \\
\hline 154 & Yemen, Rep. & 0.0287 & 0.0213 & 62 & & & & 0.439 & 0.488 & 111 \\
\hline 155 & Zambia & -0.0196 & -0.0044 & 139 & 0.2167 & 0.1217 & 77 & 0.432 & 0.455 & 118 \\
\hline 156 & Zimbabwe & 0.0064 & 0.0259 & 41 & 0.3423 & 0.1130 & 85 & 0.563 & 0.599 & 98 \\
\hline
\end{tabular}

Source : Appendix Table 2 \& Regression Equations 1 to 3.

Table 9 presents the predicted values and the observed values of each of these three indicators for different countries for 2001-10 and 1981-90. The table predicts a more even growth of per capita real GDP during the first decade of the twenty-first century. It also predicts strong growth in the developed countries and considerable swings in the growth of the net inflows of FDI. Based on our prediction of the three performance indicators, 15 economies are likely to be among the top performers of the next decade and would obviously invite the attention of the business community. These countries, in the 
alphabetical order, are: Argentina, Australia, Chile, Costa Rica, Cyprus, Czech Republic, Finland, Hungary, Ireland, Malaysia, Malta, Mexico, Norway, Portugal, and Spain. There may be genuine surprises in store as far as the other 35 top performers of the future are concerned. This is because four of our seven indicators of economic performance do not depend on the past performance. They are largely governed by the policies and changes in economic environment. Therefore, while we can identify some of the 50 top performers of the future, we may not be able to identify most of them.

\section{References}

Abramovitz, M. (1956): "Resource and Output Trends in United States since 1870", American Economic Review, Papers and Proceeding, Vol. 46, May, pp. $115-23$

Arnold D.J. and Quelch J.A. (1998): "New Strategies in Emerging Economies", Sloan Management Review Vol. 40, No.1, pp.7-20

Auer, L. (1979): Regional Disparities of Productivity and Growth in Canada, Economic Council of Canada.

Barro, R.J. (1997): Determinants of economic growth - A cross-country empirical study, Cambridge, MIT Press

Bils, Mark, and P. Klenow (1996): "Does Schooling cause Growth?", American Economic Review, Vol. 90, No. 5, pp. 1160-83

Biswas, Basudeb and Frank Caliendo (2002): "A Multivariate Analysis of the Human Development Index", Indian Economic Journal, Vol. 49, No.4, AprilJune, pp. 96-100

Blomstrom, Magnus, R. Lipsey, and M. Zejan (1996): "Is Fixed Investment the Key to Economic Growth?", Quarterly Journal of Economics, Vol. 111 No. 1, pp. 269-76

Bonnici, Josef (2002): 'Inaugural Address', Malta External Trade Corporation Conference on "Think Global - Act How?", Feb. 6

Denison, E. (1967): Why Growth Rates Differ: Post War Experience in Nine Westerns Countries, Washington DC, Brooking Institute

Easterly, William and Ross Levine (2001): "It's Not Factor Accumulation: Stylized Facts and Growth Models", World Bank Economic Review, Vol. 15, No. 3 pp.177-219 
DeSilva, Gamini, R.O. Thattil, S. Samita Gamini (2000): "Construction of a Composite Index of Human Development for Developing Nations", IAOS Conference on Statistics Development and Human Rights, held at Montreaux (Switzerland), 4-8 September.

Global Edge (2002): http://ciber.msu.edu/Research/MPI/default.asp

Goyal, Arun and Noor Mohd (eds.) (2001): WTO in the New Millennium: Commentary, Case Law and Legal Texts, Fifth Edition, Bombay: MUIRDC World Trade Centre, September

Güveli, Serdar K (2000): “ A Ranking of Islamic Countries in Terms of their Levels of Socio-Economic Development", Journal of Economic Cooperation, Vol. 21, No. 1, pp.97-114

Hoskisson R.E. Eden L., Lan C.M. and Wright (2000): "Strategy in Emerging Economies", Academy of Management Journal, Vol. 43, Issue 3, June; pp. $249-67$

International Finance Corporation (IFC) (1999): Database from http://www.ifc.org/EMBD/SLIDES/img009.gif

International Monetary Fund (2003): International Financial Statistics, Washington DC

Jalan Bimal (2002): "Financial Architecture: To Each His Own", address delivered to the symposium of Central Bank Governors hosted by the Bank of England at London, July 5.

Kapur, Devesh and Urjit R. Patel (2003): "Large Foreign Currency Reserves: Insurance for Domestic Weakness and External Uncertainties", Economic and Political Weekly, Vol. 38 No. 11, March 15, pp. 1047-53

Morris, David Morris (1979): Measuring the Conditions of The World's Poor: The Physical Quality of Life Index, Washington DC: Overseas Development Council.

Nelson R. (1964): "Aggregate Production Functions and Medium Range Growth Projections", American Economic Review, Vol.54, No. 5, Sept., pp. 575-606

Solow, R (1957): "Technical Change and the Aggregate Production Function", Review of Economics and Statistics, Vol. 39, August, pp. 312-20

Teranishi Juro (1992): Import Substitution Policy in Japan's Economic Development, Tokyo: Institute of Economic Research, Hototsubashi University

UNDP (2002): Human Development Report 2002, New York

World Bank (2003): Global Economic Prospects and the Developing Countries, Washington DC: WBDP 
World Bank (2002): World Development Indicators 2002, (on CD-ROM), Washington DC

World Bank (1991): World Development Report 1991, Washington DC

World Economic Forum (WEF) (2002): The Global Competitiveness Report 2001-02, New York: Oxford University Press

World Economic Forum (WEF) (1999): The Global Competitiveness Report 1998-99, New York: Oxford University Press

Young A. (1995): "The Tyranny of Numbers: Confronting the Statistical Realities of the East Asian Growth Experience", Quarterly Journal of Economics, Vol. 110 , No. 3, August, pp. 641-80 


\begin{tabular}{|c|c|c|c|c|c|c|c|c|}
\hline \multirow{3}{*}{ No. } & \multicolumn{8}{|c|}{ Appendix 1: Values of the 7 Indicators of Economic Performance by Countries During 1980s } \\
\hline & Countries & & & Exponential Tren & Rates 0 & Juring 1980 & $s$ for & \\
\hline & & GDP pc & GCF & $\begin{array}{l}\text { Imports of } \\
\text { Goods \& Serv. }\end{array}$ & FDI & \begin{tabular}{|l} 
Forex \\
Reserves
\end{tabular} & \begin{tabular}{|l} 
Average \\
Infl. Rate
\end{tabular} & $\begin{array}{l}\text { HDI } \\
(1985)\end{array}$ \\
\hline 1 & Afghanistan & & & & & -0.0244 & & \\
\hline 2 & Albania & -0.0082 & -0.0104 & & & & & 0.691 \\
\hline 3 & Algeria & -0.0016 & -0.0264 & -0.0571 & 0.6439 & -0.1638 & 9.7403 & 0.600 \\
\hline 4 & Angola & 0.0080 & & & -0.1239 & & & \\
\hline 5 & Antigua and Barbuda & 0.0657 & 0.0925 & 0.0680 & & 0.1332 & 6.4708 & \\
\hline 6 & Argentina & -0.0190 & -0.0439 & -0.0418 & 0.0766 & -0.0015 & 787.0115 & 0.805 \\
\hline 7 & Armenia & & & & & & & \\
\hline 8 & Aruba & & & & & 0.0407 & 3.6166 & \\
\hline 9 & Australia & 0.0216 & 0.0346 & 0.0576 & 0.1965 & 0.1312 & 8.1277 & 0.873 \\
\hline 10 & Austria & 0.0221 & 0.0331 & 0.0506 & 0.1265 & 0.0395 & 3.5296 & 0.867 \\
\hline 11 & Azerbaijan & -0.0825 & & & & & & \\
\hline 12 & Bahamas, The & 0.0244 & & & & 0.0153 & 5.5348 & 0.817 \\
\hline 13 & Bahrain & -0.0106 & -0.0409 & 0.0094 & & -0.0683 & 1.9567 & \\
\hline 14 & Bangladesh & 0.0145 & 0.0192 & 0.0646 & -0.2326 & 0.1274 & 7.3649 & 0.386 \\
\hline 15 & Barbados & 0.0241 & -0.0044 & -0.0246 & 0.1684 & -0.0244 & 5.7497 & \\
\hline 16 & Belarus & 0.0368 & 0.0448 & & & & & \\
\hline 17 & Belgium & 0.0225 & 0.0495 & 0.0482 & 0.2032 & 0.0755 & 3.4088 & 0.875 \\
\hline 18 & Belize & 0.0263 & 0.0988 & 0.0453 & 0.3583 & 0.2356 & 4.1761 & 0.718 \\
\hline 19 & Benin & -0.0099 & -0.0608 & -0.0606 & & -0.0290 & 3.0037 & 0.350 \\
\hline 20 & Bhutan & 0.0517 & 0.0318 & -0.0286 & & 0.1017 & 9.1954 & \\
\hline 21 & Bolivia & -0.0198 & 0.0257 & 0.0597 & -0.1419 & -0.0191 & 1380.1453 & 0.573 \\
\hline 22 & Bosnia and Herz. & & & & & & & \\
\hline 23 & Botswana & 0.0637 & 0.1293 & 0.1100 & 0.0616 & 0.2925 & 10.5841 & 0.613 \\
\hline 24 & Brazil & 0.0127 & 0.0471 & 0.0202 & -0.0803 & 0.0028 & 613.8457 & 0.692 \\
\hline 25 & Brunei & -0.0263 & & & & & & \\
\hline 26 & Bulgaria & 0.0329 & 0.0194 & -0.0495 & & & 7.5970 & 0.784 \\
\hline 27 & Burkina Faso & 0.0092 & 0.0800 & 0.0280 & -0.0983 & 0.1703 & 1.3416 & 0.282 \\
\hline 28 & $\mid$ Burundi & 0.0134 & 0.0469 & 0.0047 & -0.1675 & 0.1004 & 7.6247 & 0.338 \\
\hline 29 & Cambodia & 0.0195 & & & & & & \\
\hline 30 & Cameroon & -0.0065 & -0.0553 & 0.0160 & -0.2430 & -0.0880 & 8.2524 & 0.505 \\
\hline 31 & Canada & 0.0222 & 0.0560 & 0.0785 & 0.3591 & 0.1681 & 5.9693 & 0.906 \\
\hline 32 & Cape Verde & 0.0397 & -0.0486 & 0.0318 & & 0.0662 & 7.2352 & 0.587 \\
\hline 33 & Central African Rep. & -0.0107 & & & 0.0543 & 0.0715 & 3.2543 & 0.371 \\
\hline 34 & Chad & 0.0341 & & 0.1087 & -0.2529 & 0.2346 & 2.5345 & 0.298 \\
\hline 35 & Chile & 0.0321 & 0.0907 & 0.0357 & 0.0942 & 0.0447 & 20.4466 & 0.754 \\
\hline 36 & China & 0.0823 & 0.1072 & 0.0928 & 0.2599 & 0.0829 & 11.8369 & 0.591 \\
\hline 37 & Colombia & 0.0169 & 0.0113 & 0.0029 & 0.0066 & -0.0080 & 23.7236 & 0.704 \\
\hline 38 & Comoros & -0.0013 & -0.0487 & -0.0084 & & 0.1391 & & 0.498 \\
\hline 39 & Congo, Dem. Rep. & -0.0171 & -0.0511 & 0.1060 & & 0.0637 & 60.4205 & 0.517 \\
\hline 40 & Congo, Rep. & -0.0104 & -0.1885 & -0.0781 & -0.1341 & -0.2793 & 1.3448 & \\
\hline 41 & Costa Rica & 0.0070 & 0.0707 & 0.0928 & 0.1266 & 0.1180 & 27.1867 & 0.770 \\
\hline 42 & Cote d'Ivoire & -0.0292 & -0.1037 & -0.0217 & 0.0212 & -0.0341 & 5.1972 & 0.412 \\
\hline 43 & Croatia & & & & & & 453.8095 & \\
\hline 44 & Cyprus & 0.0529 & 0.0386 & 0.0442 & 0.0207 & 0.0932 & 4.8960 & 0.821 \\
\hline 45 & Czech Republic & & & & & & & \\
\hline 46 & Denmark & 0.0204 & 0.0552 & 0.0479 & 0.5453 & 0.1407 & 5.9457 & 0.883 \\
\hline 47 & Djibouti & -0.0767 & & & & 0.0402 & & \\
\hline 48 & Dominica & & 0.0628 & 0.0554 & 0.5195 & 0.1911 & 4.6900 & \\
\hline 49 & Dominican Republic & 0.0092 & 0.0564 & 0.1230 & 0.1580 & -0.0892 & 24.2451 & 0.667 \\
\hline 50 & Ecuador & -0.0057 & -0.0317 & -0.0068 & 0.0922 & -0.0125 & 37.5211 & 0.694 \\
\hline 51 & Egypt, Arab Rep. & 0.0258 & -0.0113 & -0.0226 & 0.0920 & 0.0903 & 16.9603 & 0.532 \\
\hline 52 & El Salvador & -0.0004 & 0.0351 & 0.0186 & -0.2099 & 0.0888 & 19.1870 & 0.606 \\
\hline 53 & Equatorial Guinea & -0.0087 & & 0.0580 & & -0.0421 & & 0.533 \\
\hline 54 & Eritrea & & & & & & & \\
\hline 55 & Estonia & 0.0137 & -0.0097 & & & & & \\
\hline 56 & Ethiopia & -0.0191 & 0.0205 & 0.0146 & & -0.2155 & 4.6646 & 0.275 \\
\hline 57 & Fiji & -0.0013 & -0.1481 & -0.0463 & -0.0330 & 0.0487 & 6.8230 & 0.697 \\
\hline 58 & Finland & 0.0295 & 0.0387 & 0.0519 & 0.4559 & 0.1784 & 6.7690 & 0.873 \\
\hline 59 & France & 0.0205 & 0.0406 & 0.0497 & 0.2343 & 0.0242 & 6.3683 & 0.875 \\
\hline 60 & French Polynesia & 0.0265 & & & & & & \\
\hline
\end{tabular}




\begin{tabular}{|c|c|c|c|c|c|c|c|c|}
\hline \multicolumn{9}{|c|}{ Appendix 1: Values of the 7 Indicators of Economic Performance by Countries During 1980s (contd.) } \\
\hline \multirow[t]{2}{*}{ No. } & \multirow[t]{2}{*}{ Countries } & \multicolumn{7}{|c|}{ Exponential Trend Rates during 1980s for } \\
\hline & & GDP pc & GCF & $\begin{array}{l}\text { Imports of } \\
\text { Goods \& Serv. }\end{array}$ & FDI & $\begin{array}{l}\text { Forex } \\
\text { Reserves }\end{array}$ & $\begin{array}{l}\text { Average } \\
\text { Infl. Rate }\end{array}$ & $\begin{array}{l}\text { HDI } \\
(1985)\end{array}$ \\
\hline 61 & Gabon & -0.0232 & -0.0833 & -0.0462 & 0.0580 & -0.1922 & 6.0306 & \\
\hline 62 & Gambia, The & -0.0024 & 0.0072 & -0.0506 & & 0.2624 & 18.0077 & \\
\hline 63 & Georgia & -0.0090 & & & & & & \\
\hline 64 & Germany & 0.0237 & 0.0284 & 0.0387 & 0.2234 & 0.0245 & 2.6323 & 0.868 \\
\hline 65 & Ghana & 0.0017 & 0.0496 & 0.0343 & 0.0281 & 0.0273 & 46.9867 & 0.481 \\
\hline 66 & Greece & 0.0064 & 0.0010 & 0.0504 & 0.0876 & 0.1378 & 19.0408 & 0.845 \\
\hline 67 & Grenada & 0.0571 & 0.0512 & 0.0289 & 0.2772 & 0.0072 & 5.2858 & \\
\hline 68 & Guatemala & -0.0142 & -0.0135 & -0.0003 & 0.0324 & 0.0367 & 15.1069 & \\
\hline 69 & Guinea & 0.0161 & 0.0320 & 0.0517 & 0.5113 & & & \\
\hline 70 & Guinea-Bissau & 0.0107 & 0.1373 & -0.0069 & 0.3466 & -0.0524 & & 0.283 \\
\hline 71 & Guyana & -0.0241 & -0.0698 & -0.0581 & & 0.0485 & & 0.671 \\
\hline 72 & Haiti & -0.0190 & -0.0089 & 0.0293 & 0.0161 & -0.0679 & 6.9648 & 0.445 \\
\hline 73 & Honduras & -0.0017 & 0.0537 & 0.0274 & 0.1559 & -0.1800 & 7.9234 & 0.597 \\
\hline 74 & Hong Kong, China & 0.0549 & 0.0423 & 0.1340 & & & 8.0906 & 0.823 \\
\hline 75 & Hungary & 0.0158 & -0.0059 & 0.0192 & & -0.0966 & 10.9270 & 0.805 \\
\hline 76 & Iceland & 0.0200 & 0.0115 & 0.0300 & & 0.0757 & 34.8599 & 0.894 \\
\hline 77 & India & 0.0354 & 0.0653 & 0.0599 & 0.2109 & -0.0821 & 8.8793 & 0.473 \\
\hline 78 & Indonesia & 0.0414 & 0.0716 & 0.0003 & 0.1914 & 0.0219 & 8.6074 & 0.582 \\
\hline 79 & Iran, Islamic Rep. & -0.0210 & -0.0207 & -0.0496 & & & 18.5211 & 0.607 \\
\hline 80 & Ireland & 0.0315 & -0.0063 & 0.0574 & -0.1125 & 0.0553 & 7.8471 & 0.846 \\
\hline 81 & Israel & 0.0174 & 0.0223 & 0.0405 & 0.1225 & 0.0277 & 118.2897 & 0.836 \\
\hline 82 & Italy & 0.0257 & 0.0287 & 0.0645 & 0.0660 & 0.0950 & 9.7217 & 0.856 \\
\hline 83 & Jamaica & 0.0101 & -0.0114 & 0.0940 & & 0.0365 & 15.0669 & 0.692 \\
\hline 84 & Japan & 0.0360 & 0.0601 & 0.0654 & 0.2997 & 0.1382 & 2.0582 & 0.893 \\
\hline 85 & Jordan & -0.0171 & -0.0208 & 0.0101 & -0.2015 & -0.1290 & 7.5299 & 0.658 \\
\hline 86 & Kazakhstan & & & & & & & \\
\hline 87 & Kenya & 0.0100 & 0.0187 & 0.0445 & 0.0475 & -0.0447 & 11.9111 & 0.512 \\
\hline 88 & Kiribati & -0.0171 & & & & & & \\
\hline 89 & Korea, Rep. & 0.0761 & 0.1200 & 0.1126 & 0.3467 & 0.1871 & 6.3942 & 0.774 \\
\hline 90 & Kuwait & -0.0105 & -0.0200 & 0.0206 & & -0.1283 & 3.8790 & 0.777 \\
\hline 91 & Kyrgyz Republic & 0.0440 & & & & & & \\
\hline 92 & Lao PDR & 0.0098 & & & & & & 0.374 \\
\hline 93 & Latvia & 0.0287 & 0.0206 & & & & & 0.802 \\
\hline 94 & Lebanon & -0.1790 & & & 0.0788 & -0.1151 & & \\
\hline 95 & Lesotho & 0.0266 & 0.0601 & 0.0333 & 0.1887 & -0.0013 & 13.3925 & 0.547 \\
\hline 96 & Liberia & & & & 0.0197 & -0.0526 & & \\
\hline 97 & Libya & & & & & -0.0728 & & \\
\hline 98 & Lithuania & 0.0629 & & & & & & \\
\hline 99 & Luxembourg & 0.0481 & 0.0733 & 0.0622 & & & 4.4578 & 0.860 \\
\hline 100 & Macao, China & 0.0372 & 0.0722 & 0.0668 & & 0.3159 & 9.6485 & \\
\hline 101 & Macedonia, FYR & & & & & & & \\
\hline 102 & Madagascar & -0.0091 & 0.0818 & -0.0393 & 0.2355 & 0.2287 & 17.9211 & 0.427 \\
\hline 103 & Malawi & -0.0040 & -0.0155 & 0.0131 & & 0.1470 & 16.3066 & 0.354 \\
\hline 104 & Malaysia & 0.0229 & 0.0235 & 0.0679 & 0.0102 & 0.0738 & 3.2481 & 0.693 \\
\hline 105 & Maldives & 0.0706 & & & 0.0063 & 0.2372 & & 0.629 \\
\hline 106 & Mali & -0.0132 & 0.0453 & 0.0668 & 0.1420 & 0.1907 & & 0.292 \\
\hline 107 & Malta & 0.0397 & 0.0870 & 0.0816 & 0.0580 & 0.0044 & 2.2998 & 0.793 \\
\hline 108 & Mauritania & -0.0056 & 0.0503 & -0.0151 & -0.1156 & -0.1367 & 7.2876 & 0.379 \\
\hline 109 & Mauritius & 0.0535 & 0.0942 & 0.1310 & 0.4152 & 0.3921 & 8.3024 & 0.686 \\
\hline 110 & Mexico & -0.0116 & -0.0264 & 0.0311 & 0.1195 & 0.1161 & 69.0783 & 0.752 \\
\hline 111 & Micronesia, Fed. Sts. & 0.0094 & & & & & & \\
\hline 112 & Moldova & 0.0171 & & & & & & 0.741 \\
\hline 113 & Mongolia & 0.0299 & & & & & 9.0032 & 0.650 \\
\hline 114 & Morocco & 0.0227 & 0.0150 & 0.0353 & 0.0883 & 0.1940 & 7.3253 & 0.508 \\
\hline 115 & Mozambique & -0.0084 & 0.0458 & -0.0323 & 0.2983 & 0.2483 & & 0.290 \\
\hline 116 & Myanmar & 0.0089 & -0.0504 & -0.1478 & & 0.0073 & 11.7881 & \\
\hline 117 & Namibia & -0.0210 & 0.0003 & 0.0057 & & & 12.9369 & \\
\hline 118 & Nepal & 0.0227 & 0.0582 & 0.0553 & 0.1920 & 0.0210 & 10.1938 & 0.370 \\
\hline
\end{tabular}




\begin{tabular}{|c|c|c|c|c|c|c|c|c|}
\hline \multicolumn{9}{|c|}{ Appendix 1: Values of the 7 Indicators of Economic Performance by Countries During 1980s (contd.) } \\
\hline \multirow[t]{2}{*}{ No. } & \multirow[t]{2}{*}{ Countries } & \multicolumn{7}{|c|}{\begin{tabular}{|c|} 
Exponential Trend Rates during 1980s for \\
\end{tabular}} \\
\hline & & GDP pc & GCF & $\begin{array}{l}\text { Imports of } \\
\text { Goods \& Serv. }\end{array}$ & |FDI & \begin{tabular}{|l} 
Forex \\
Reserves
\end{tabular} & \begin{tabular}{|l} 
Average \\
Infl. Rate
\end{tabular} & \begin{tabular}{|l} 
HDI \\
$(1985)$
\end{tabular} \\
\hline 119 & Netherlands & 0.0203 & 0.0412 & 0.0478 & 0.2324 & 0.0397 & 2.4606 & 0.888 \\
\hline 120 & Netherlands Antilles & & & & -0.3380 & 0.0207 & 3.8940 & \\
\hline 121 & New Caledonia & 0.0470 & & & & & & \\
\hline 122 & New Zealand & 0.0067 & 0.0148 & 0.0427 & 0.2378 & 0.1869 & 10.8799 & 0.866 \\
\hline 123 & Nicaragua & -0.0515 & -0.0745 & -0.0270 & & & 2438.8706 & 0.584 \\
\hline 124 & Niger & -0.0299 & -0.0406 & -0.0666 & & 0.1555 & 2.4573 & 0.246 \\
\hline 125 & Nigeria & -0.0024 & -0.0755 & -0.1576 & 0.0828 & -0.0482 & 22.8090 & 0.403 \\
\hline 126 & Norway & 0.0244 & 0.0056 & 0.0268 & 0.2068 & 0.0727 & 7.6645 & 0.888 \\
\hline 127 & Oman & 0.0356 & & 0.0077 & -0.0202 & 0.0461 & -1.4051 & \\
\hline 128 & Pakistan & 0.0339 & 0.0521 & 0.0318 & 0.1653 & -0.1497 & 6.9769 & 0.404 \\
\hline 129 & Panama & -0.0215 & -0.0989 & -0.0230 & 0.5903 & -0.0159 & 1.8440 & 0.745 \\
\hline 130 & Papua New Guinea & -0.0055 & -0.0098 & -0.0139 & 0.0682 & -0.0427 & 5.8293 & 0.462 \\
\hline 131 & Paraguay & -0.0049 & 0.0014 & 0.0644 & 0.0185 & -0.0955 & 22.0446 & 0.705 \\
\hline 132 & Peru & -0.0245 & -0.0377 & -0.0363 & 0.6091 & -0.1004 & 1223.5745 & 0.692 \\
\hline 133 & Philippines & -0.0139 & -0.0180 & 0.0447 & 0.3572 & -0.0227 & 13.6717 & 0.688 \\
\hline 134 & Poland & -0.0736 & & & 0.0600 & 0.2022 & 107.6725 & \\
\hline 135 & Portugal & 0.0337 & 0.0414 & 0.0800 & 0.3240 & 0.2584 & 17.3141 & 0.787 \\
\hline 136 & Puerto Rico & 0.0347 & & & & & & \\
\hline 137 & Qatar & & & -0.0577 & & 0.0289 & 3.5179 & \\
\hline 138 & Romania & -0.0027 & 0.0712 & -0.0052 & & 0.0479 & 22.2534 & 0.794 \\
\hline 139 & Russian Federation & 0.0156 & & & & & & 0.827 \\
\hline 140 & Rwanda & -0.0104 & 0.0280 & 0.0145 & -0.0334 & -0.1212 & 4.3928 & 0.396 \\
\hline 141 & Samoa & 0.0126 & & & & 0.3342 & 11.6723 & 0.650 \\
\hline 142 & Sao Tome and Principe & -0.0101 & -0.0079 & 0.0498 & & & & \\
\hline 143 & Saudi Arabia & -0.0470 & -0.0465 & -0.0013 & & -0.1237 & -0.1339 & 0.670 \\
\hline 143 & Saudi Arabia & -0.0470 & -0.0465 & -0.0013 & & -0.1237 & -0.1339 & 0.670 \\
\hline 144 & Senegal & 0.0015 & 0.0509 & 0.0152 & & 0.0145 & 6.0680 & 0.356 \\
\hline 145 & Seychelles & 0.0410 & 0.0980 & 0.1480 & 0.1144 & -0.0141 & 3.0784 & \\
\hline 146 & Sierra Leone & -0.0089 & & -0.0136 & -0.1737 & -0.1527 & 72.7535 & \\
\hline 147 & Singapore & 0.0471 & 0.0237 & & 0.1437 & 0.1002 & 2.2843 & 0.782 \\
\hline 148 & Slovak Republic & 0.0154 & 0.0028 & 0.0360 & & & & 0.813 \\
\hline 149 & Slovenia & & & & & & & \\
\hline 150 & Solomon Islands & 0.0283 & & & 0.4004 & -0.0695 & 12.1204 & \\
\hline 151 & Somalia & & & & & -0.0122 & & \\
\hline 152 & South Africa & -0.0158 & -0.0562 & -0.0030 & & -0.0030 & 14.6664 & 0.683 \\
\hline 153 & Spain & 0.0298 & 0.0674 & 0.0949 & 0.2457 & 0.1844 & 9.3628 & 0.855 \\
\hline 154 & Sri Lanka & 0.0234 & 0.0076 & 0.0057 & -0.0397 & -0.0557 & 12.3626 & 0.676 \\
\hline 155 & St. Kitts and Nevis & 0.0765 & 0.1377 & 0.0626 & 0.3604 & 0.1600 & 3.4399 & \\
\hline 156 & St. Lucia & 0.0596 & 0.0742 & 0.0972 & 0.0272 & 0.1885 & 4.2976 & \\
\hline 157 & St. Vincent and Gren. & 0.0523 & 0.0688 & 0.0490 & 0.3102 & 0.1445 & 4.5265 & \\
\hline 158 & Sudan & -0.0245 & & & & -0.0727 & 40.2020 & 0.395 \\
\hline 159 & Suriname & -0.0287 & -0.0926 & -0.2061 & & -0.3177 & 13.6941 & \\
\hline 160 & Swaziland & 0.0385 & 0.0227 & 0.0469 & 0.3516 & 0.0693 & 14.5265 & 0.569 \\
\hline 161 & Sweden & 0.0233 & 0.0589 & 0.0512 & 0.2809 & 0.1287 & 7.6141 & 0.883 \\
\hline 162 & Switzerland & 0.0162 & 0.0447 & 0.0535 & 0.2032 & 0.0456 & 3.4088 & 0.892 \\
\hline 163 & Syrian Arab Republic & -0.0208 & -0.0663 & 0.0029 & 0.1856 & -0.0374 & 22.6213 & 0.614 \\
\hline 164 & Tajikistan & -0.0104 & -0.0700 & & & & & 0.740 \\
\hline 165 & Tanzania & 0.0214 & & & & 0.2494 & 30.6311 & \\
\hline 166 & Thailand & 0.0594 & 0.0979 & 0.1222 & 0.2462 & 0.2044 & 4.4398 & 0.676 \\
\hline 167 & Togo & -0.0103 & 0.0426 & 0.0362 & -0.0923 & 0.0552 & 3.9064 & 0.440 \\
\hline 168 & Tonga & 0.0193 & & & -0.0693 & 0.0426 & 10.2489 & \\
\hline 169 & Trinidad and Tobago & -0.0256 & -0.1122 & 0.0217 & 0.4437 & -0.3699 & 11.0800 & 0.774 \\
\hline 170 & Tunisia & 0.0077 & -0.0247 & 0.0145 & -0.1763 & 0.0277 & 7.4325 & 0.613 \\
\hline 171 & Turkey & 0.0300 & 0.0617 & 0.0984 & 0.2769 & 0.1467 & 46.2873 & 0.654 \\
\hline 172 & Turkmenistan & -0.0088 & & & & & & \\
\hline 173 & Uganda & 0.0037 & 0.0770 & 0.0430 & & -0.1121 & 103.4137 & 0.386 \\
\hline 174 & Ukraine & -0.0009 & & & & & & \\
\hline 175 & United Arab Emirates & -0.0686 & & & & 0.0519 & & \\
\hline
\end{tabular}




\begin{tabular}{|c|c|c|c|c|c|c|c|c|}
\hline \multicolumn{9}{|c|}{ Appendix 1: Values of the 7 Indicators of Economic Performance by Countries During 1980s(concl.) } \\
\hline & \multirow[t]{2}{*}{ Countries } & \multicolumn{7}{|c|}{ Exponential Trend Rates during 1980s for } \\
\hline & & GDP pc & GCF & $\begin{array}{l}\text { Imports of } \\
\text { Goods \& Serv. }\end{array}$ & FDI & \begin{tabular}{|l} 
Forex \\
Reserves
\end{tabular} & $\begin{array}{l}\text { Average } \\
\text { Infl. Rate }\end{array}$ & $\begin{array}{l}\text { HDI } \\
(1985)\end{array}$ \\
\hline \begin{tabular}{|c|}
176 \\
\end{tabular} & United Kingdom & 0.0318 & 0.0678 & 0.0681 & 0.3807 & 0.1227 & 6.5854 & 0.858 \\
\hline 177 & United States & 0.0275 & 0.0399 & 0.0790 & 0.1786 & 0.0797 & 4.7401 & 0.898 \\
\hline 178 & Uruguay & 0.0054 & -0.0495 & 0.0131 & 0.1175 & 0.0639 & 62.4875 & 0.781 \\
\hline 179 & Uzbekistan & 0.0176 & & & & & & \\
\hline 180 & Vanuatu & -0.0005 & 0.0593 & 0.0057 & 0.0942 & 0.2140 & 8.3827 & \\
\hline 181 & Venezuela, RB & -0.0110 & -0.0538 & -0.0200 & 0.0360 & -0.0826 & 24.9270 & 0.738 \\
\hline 182 & Vietnam & 0.0219 & & & & & & 0.583 \\
\hline 183 & West Bank and Gaza & & & & & & & \\
\hline 184 & Yemen, Rep. & & & & -0.5380 & & & \\
\hline 185 & Yugoslavia, Fed. Rep. & & & & & & & \\
\hline 186 & Zambia & -0.0202 & -0.0301 & -0.0031 & 0.2650 & 0.0799 & 76.8615 & 0.480 \\
\hline 187 & Zimbabwe & -0.0036 & 0.0354 & 0.0307 & & -0.0125 & 14.0014 & 0.621 \\
\hline
\end{tabular}

Basic Source: (1) World Development Indicators 2002 (on CD ROM)

(2) International Financial Statistics 2003 (online: http://ifs.apdi.net)

(3) Human Development Report 2002 (online: http://hdr.undp.org) 


\begin{tabular}{|c|c|c|c|c|c|c|c|c|}
\hline & Appendix 2: Values & 7 Indic & tors of $\mathrm{E}$ & Imic Perto & ance by & Intrles & uring 1990s & \\
\hline No. & Countries & & & Exponential Trer & Rates d & Iring 1990s & & \\
\hline & & GDP pc & GCF & $\begin{array}{l}\text { Imports of } \\
\text { Goods \& Serv. }\end{array}$ & FDI & \begin{tabular}{|l} 
Forex \\
Reserves
\end{tabular} & $\begin{array}{l}\text { Average } \\
\text { Infl. Rate }\end{array}$ & $\begin{array}{l}\text { HDI } \\
(1995)\end{array}$ \\
\hline 1 & Afghanistan & & & & & & & \\
\hline 2 & Albania & 0.0438 & 0.1970 & 0.1057 & 0.1021 & 0.1329 & 45.3730 & 0.702 \\
\hline 3 & Algeria & 0.0028 & 0.0044 & 0.0023 & -0.0846 & 0.2207 & 18.7801 & 0.663 \\
\hline 4 & Angola & -0.0080 & & & 0.1922 & 0.2403 & 1044.5208 & \\
\hline 5 & Antigua and Barbuda & 0.0286 & 0.0207 & 0.0300 & & 0.0704 & 2.5180 & \\
\hline 6 & Argentina & 0.0224 & 0.0502 & 0.1063 & 0.2042 & 0.1490 & 21.4237 & 0.830 \\
\hline 7 & Armenia & 0.0018 & 0.0656 & -0.1179 & 0.5094 & 0.6214 & 739.9026 & 0.715 \\
\hline 8 & Aruba & & & & & 0.0579 & 3.8736 & \\
\hline 9 & Australia & 0.0300 & 0.0701 & 0.0842 & 0.0675 & 0.0515 & 2.2212 & 0.927 \\
\hline 10 & Austria & 0.0172 & 0.0207 & 0.0584 & 0.2592 & 0.0532 & 2.3185 & 0.909 \\
\hline 11 & Azerbaijan & -0.0583 & 0.0544 & 0.0559 & 0.2390 & 0.9996 & 459.2728 & \\
\hline 12 & Bahamas, The & 0.0055 & & & 0.6045 & 0.1086 & 2.5162 & 0.816 \\
\hline 13 & Bahrain & 0.0090 & -0.0232 & -0.0049 & & 0.0033 & 1.0329 & \\
\hline 14 & Bangladesh & 0.0304 & 0.0933 & 0.1034 & 0.6091 & -0.0122 & 5.2992 & 0.445 \\
\hline 15 & Barbados & 0.0233 & 0.0741 & 0.0450 & 0.0791 & 0.1650 & 2.8245 & \\
\hline 16 & Belarus & -0.0060 & -0.0825 & -0.0773 & 0.4670 & 0.1487 & 637.6623 & 0.776 \\
\hline 17 & Belgium & 0.0187 & 0.0308 & 0.0452 & 0.2734 & -0.0069 & 1.9597 & 0.927 \\
\hline 18 & Belize & 0.0139 & 0.0304 & 0.0270 & 0.0739 & 0.0810 & 1.7580 & 0.772 \\
\hline 19 & Benin & 0.0191 & 0.0596 & 0.0260 & 0.2342 & 0.0560 & 9.0075 & 0.388 \\
\hline 20 & Bhutan & 0.0359 & 0.0815 & -0.0059 & & 0.1870 & 9.8459 & \\
\hline 21 & Bolivia & 0.0155 & 0.0783 & 0.0513 & 0.3402 & 0.2123 & 9.1674 & 0.630 \\
\hline 22 & Bosnia and Herzegovina & 0.1840 & 0.3047 & 0.1960 & & & & \\
\hline 23 & Botswana & 0.0234 & -0.0046 & 0.0147 & -0.1791 & 0.0728 & 10.5134 & 0.620 \\
\hline 24 & Brazil & 0.0159 & 0.0344 & 0.1148 & 0.4325 & 0.1169 & 549.2097 & 0.737 \\
\hline 25 & Brunei & -0.0064 & & & & & & \\
\hline 26 & Bulgaria & -0.0104 & -0.0190 & 0.0527 & 0.3910 & 0.2224 & 187.2285 & 0.778 \\
\hline 27 & Burkina Faso & 0.0230 & 0.0749 & 0.0182 & -0.0250 & -0.0012 & 4.5795 & 0.300 \\
\hline 28 & Burundi & -0.0503 & -0.0069 & 0.0098 & & -0.1672 & 15.2368 & 0.316 \\
\hline 29 & Cambodia & 0.0177 & 0.1256 & 0.0980 & 0.1619 & 0.3563 & 5.3861 & 0.531 \\
\hline 30 & Cameroon & -0.0003 & 0.0194 & 0.0633 & 0.2289 & -0.4232 & 5.5965 & 0.499 \\
\hline 31 & Canada & 0.0223 & 0.0566 & 0.0778 & 0.2923 & 0.1043 & 1.9968 & 0.932 \\
\hline 32 & Cape Verde & 0.0348 & -0.0228 & 0.0844 & 0.3292 & -0.1387 & 6.1517 & 0.678 \\
\hline 33 & Central African Republic & -0.0003 & & & 0.1286 & 0.1450 & 4.3616 & 0.369 \\
\hline 34 & Chad & -0.0089 & & -0.0368 & 0.1503 & 0.1104 & 7.0622 & 0.335 \\
\hline 35 & Chile & 0.0477 & 0.0803 & 0.0999 & 0.2398 & 0.0844 & 9.5399 & 0.811 \\
\hline 36 & China & 0.0856 & 0.1067 & 0.0530 & 0.1911 & 0.2411 & 7.4735 & 0.681 \\
\hline 37 & Colombia & 0.0089 & 0.0066 & 0.0726 & 0.1840 & 0.0315 & 20.4993 & 0.750 \\
\hline 38 & Comoros & -0.0241 & -0.0595 & -0.0097 & 0.3654 & 0.1156 & & 0.506 \\
\hline 39 & Congo, Dem. Rep. & -0.0763 & 0.0075 & -0.1008 & -0.0836 & -0.0833 & 4774.2697 & 0.511 \\
\hline 40 & Congo, Rep. & -0.0361 & -0.0038 & 0.0546 & 0.1700 & 0.7124 & 8.2174 & \\
\hline 41 & Costa Rica & 0.0298 & 0.0468 & 0.0865 & 0.1261 & 0.0478 & 16.0461 & 0.805 \\
\hline 42 & Cote d'Ivoire & 0.0078 & 0.1113 & 0.0490 & 0.1263 & 0.6597 & 6.2896 & 0.416 \\
\hline 43 & Croatia & 0.0376 & 0.0805 & 0.0473 & 0.3964 & 0.3176 & 238.2516 & 0.789 \\
\hline 44 & Cyprus & 0.0316 & -0.0321 & 0.0019 & 0.0333 & 0.0501 & 3.8301 & 0.866 \\
\hline 45 & Czech Republic & 0.0164 & 0.0638 & 0.1331 & 0.2409 & 0.1479 & 7.5935 & 0.843 \\
\hline 46 & Denmark & 0.0221 & 0.0615 & 0.0579 & 0.2942 & 0.1013 & 2.1377 & 0.907 \\
\hline $\begin{array}{l}47 \\
48\end{array}$ & \begin{tabular}{|l|} 
Djibouti \\
Dominica
\end{tabular} & -0.0360 & 0.0162 & 0.0166 & $\begin{array}{l}0.2021 \\
-0.0540\end{array}$ & \begin{tabular}{|l|}
-0.0287 \\
0.0701
\end{tabular} & 2.1072 & \\
\hline 49 & Dominican Republic & 0.0444 & 0.0639 & 0.0677 & 0.2316 & 0.0384 & 11.0107 & 0.698 \\
\hline 50 & Ecuador & -0.0058 & -0.0204 & -0.0063 & 0.1587 & 0.0426 & 43.7924 & 0.719 \\
\hline 51 & Egypt, Arab Rep. & 0.0277 & 0.0821 & 0.0329 & 0.1400 & 0.0833 & 9.1127 & 0.605 \\
\hline 52 & EI Salvador & 0.0237 & 0.0551 & & 0.1864 & 0.2166 & 8.4358 & 0.682 \\
\hline 53 & Equatorial Guinea & 0.1948 & 0.3841 & 0.4202 & 0.1978 & 0.0727 & & 0.582 \\
\hline 54 & Eritrea & 0.0111 & & 0.0658 & -0.0167 & & & 0.408 \\
\hline 55 & Estonia & 0.0260 & 0.0125 & 0.0946 & 0.1729 & 0.1817 & 26.9257 & \\
\hline 56 & Ethiopia & 0.0300 & 0.1033 & 0.0688 & 0.3905 & 0.1226 & 7.3124 & 0.308 \\
\hline 57 & Fiji & 0.0063 & -0.0174 & 0.0084 & 0.0113 & 0.0584 & 3.4559 & 0.743 \\
\hline 58 & Finland & 0.0324 & 0.0414 & 0.0737 & 0.3746 & 0.0414 & 1.8628 & 0.908 \\
\hline 59 & France & 0.0146 & 0.0191 & 0.0563 & 0.1064 & 0.0511 & 1.7242 & 0.914 \\
\hline 60 & French Polynesia & 0.0017 & & & & & & \\
\hline
\end{tabular}




\begin{tabular}{|c|c|c|c|c|c|c|c|c|}
\hline \multicolumn{9}{|c|}{ Appendix 2:Values of the 7 Indicators of Economic Performance by Countries During 1990s(contd.) } \\
\hline \multirow[t]{2}{*}{ No. } & \multirow[t]{2}{*}{ Countries } & \multicolumn{7}{|c|}{ Exponential Trend Rates during 1990s for } \\
\hline & & GDP pc & GCF & $\begin{array}{l}\text { Imports of } \\
\text { Goods \& Serv. }\end{array}$ & FDI & \begin{tabular}{|l} 
Forex \\
Reserves
\end{tabular} & \begin{tabular}{|l} 
Average \\
Infl. Rate
\end{tabular} & $\begin{array}{l}\text { HDI } \\
\text { (1995) }\end{array}$ \\
\hline 61 & Gabon & 0.0008 & 0.0388 & 0.0093 & & 0.2412 & 4.2472 & \\
\hline 62 & Gambia, The & -0.0009 & 0.0327 & 0.0060 & 0.0718 & 0.0352 & 4.2936 & 0.375 \\
\hline 63 & Georgia & -0.0966 & 0.4818 & 0.1059 & 0.5642 & -0.1046 & 39.3309 & \\
\hline 64 & Germany & 0.0118 & 0.0132 & 0.0519 & 0.4441 & -0.0153 & 2.2454 & 0.907 \\
\hline 65 & Ghana & 0.0187 & 0.0226 & 0.1100 & 0.0931 & 0.1232 & 26.4052 & 0.525 \\
\hline 66 & Greece & 0.0192 & 0.0373 & 0.0638 & -0.0182 & 0.1350 & 9.3896 & 0.868 \\
\hline 67 & Grenada & 0.0326 & 0.0533 & 0.0652 & 0.1113 & 0.1534 & 2.1959 & \\
\hline 68 & Guatemala & 0.0143 & 0.0488 & 0.0823 & 0.1235 & 0.0853 & 11.2399 & 0.609 \\
\hline 69 & Guinea & 0.0187 & 0.0292 & 0.0176 & 0.2311 & 0.0975 & & \\
\hline 70 & Guinea-Bissau & -0.0147 & -0.1347 & 0.0016 & & 0.1538 & 35.0105 & 0.331 \\
\hline 71 & Guyana & 0.0458 & 0.0188 & 0.0543 & -0.1037 & 0.0791 & 6.8557 & 0.703 \\
\hline 72 & Haiti & -0.0234 & -0.0007 & 0.1046 & 0.2800 & 0.2799 & 20.5579 & 0.457 \\
\hline 73 & Honduras & 0.0025 & 0.0611 & 0.0369 & 0.2264 & 0.3079 & 15.8897 & 0.628 \\
\hline 74 & Hong Kong, China & 0.0159 & 0.0454 & 0.0709 & & 0.1552 & 5.3448 & 0.877 \\
\hline 75 & Hungary & 0.0284 & 0.1133 & 0.1167 & 0.0234 & 0.1141 & 20.2521 & 0.809 \\
\hline 76 & Iceland & 0.0224 & 0.0560 & 0.0656 & 0.0380 & 0.0038 & 3.2203 & 0.918 \\
\hline 77 & India & 0.0431 & 0.0830 & 0.0959 & 0.3470 & 0.2310 & 9.0508 & 0.545 \\
\hline 78 & Indonesia & 0.0184 & -0.0215 & 0.0413 & 0.2400 & 0.1342 & 14.1132 & 0.664 \\
\hline 79 & Iran, Islamic Rep. & 0.0154 & 0.0258 & -0.1298 & 0.3670 & & 24.3942 & 0.688 \\
\hline 80 & Ireland & 0.0684 & 0.1079 & 0.1358 & 0.3568 & 0.0351 & 2.5392 & 0.894 \\
\hline 81 & Israel & 0.0219 & 0.0307 & 0.0795 & 0.2624 & 0.2007 & 9.6304 & 0.877 \\
\hline 82 & Italy & 0.0146 & 0.0181 & 0.0497 & 0.1239 & -0.0188 & 3.7292 & 0.897 \\
\hline 83 & Jamaica & -0.0082 & 0.0071 & 0.0113 & 0.1791 & 0.1703 & 26.4231 & 0.736 \\
\hline 84 & Japan & 0.0101 & -0.0007 & 0.0453 & 0.2978 & 0.1852 & 0.8345 & 0.923 \\
\hline 85 & Jordan & 0.0107 & -0.0111 & 0.0226 & 0.8473 & 0.1365 & 3.5242 & 0.703 \\
\hline 86 & Kazakhstan & -0.0226 & -0.1486 & -0.1231 & 0.3525 & 0.1595 & 305.4336 & \\
\hline 87 & Kenya & -0.0033 & 0.0490 & 0.0736 & 0.2123 & 0.2575 & 16.0112 & 0.523 \\
\hline 88 & Kiribati & 0.0054 & & & & & & \\
\hline 89 & Korea, Rep. & 0.0433 & 0.0041 & 0.0904 & 0.3124 & 0.1990 & 5.0970 & 0.852 \\
\hline 90 & Kuwait & -0.0143 & $\mid-0.0381$ & -0.0041 & 0.0237 & 0.0398 & 2.3286 & 0.812 \\
\hline 91 & Kyrgyz Republic & -0.0399 & -0.0356 & -0.0886 & 0.2298 & 0.2235 & 24.0860 & \\
\hline 92 & Lao PDR & 0.0393 & & & 0.2494 & & 34.0969 & 0.445 \\
\hline 93 & Latvia & -0.0007 & 0.0426 & 0.0902 & 0.3131 & 0.0391 & 49.8510 & 0.763 \\
\hline 94 & Lebanon & 0.0269 & 0.0441 & -0.0092 & 0.6098 & 0.1755 & & 0.730 \\
\hline $\begin{array}{l}95 \\
96\end{array}$ & \begin{tabular}{|l|} 
Lesotho \\
Liberia
\end{tabular} & 0.0206 & 0.0014 & 0.0011 & $\begin{array}{l}0.4930 \\
-0.1111\end{array}$ & $\begin{array}{l}0.1581 \\
0.6987\end{array}$ & 11.5672 & 0.572 \\
\hline 97 & Libya & & & & & & & \\
\hline 98 & Lithuania & -0.0153 & 0.0946 & 0.0752 & 0.4751 & 0.3169 & 70.3021 & 0.781 \\
\hline 99 & Luxembourg & 0.0396 & 0.0631 & 0.0523 & & -0.0207 & 2.1842 & 0.912 \\
\hline 100 & Macao, China & -0.0030 & -0.0692 & 0.0094 & & 0.1461 & 3.3975 & \\
\hline 101 & Macedonia, FYR & -0.0076 & 0.0220 & 0.0997 & 0.3526 & 0.1980 & 24.3342 & \\
\hline 102 & Madagascar & -0.0045 & 0.0541 & 0.0632 & 0.1597 & 0.2070 & 17.3545 & 0.441 \\
\hline 103 & Malawi & 0.0186 & -0.0939 & -0.0099 & 0.2516 & 0.1846 & 32.8005 & 0.403 \\
\hline 104 & Malaysia & 0.0391 & 0.0321 & 0.0831 & -0.1203 & 0.0793 & 3.5538 & 0.760 \\
\hline 105 & Maldives & 0.0568 & 0.0704 & 0.0895 & 0.0799 & 0.2296 & 7.4807 & 0.707 \\
\hline 106 & Mali & 0.0147 & -0.0045 & 0.0287 & 0.1758 & 0.0403 & 4.0512 & 0.346 \\
\hline 107 & Malta & 0.0381 & -0.0032 & 0.0200 & 0.2839 & 0.0275 & 2.8937 & 0.850 \\
\hline 108 & Mauritania & 0.0128 & 0.1076 & 0.0230 & -0.1631 & 0.2124 & 6.0479 & 0.418 \\
\hline 109 & Mauritius & 0.0399 & 0.0392 & 0.0522 & 0.2164 & -0.0089 & 6.6819 & 0.746 \\
\hline 110 & Mexico & 0.0147 & 0.0444 & 0.1160 & 0.1298 & 0.1014 & 18.6899 & 0.774 \\
\hline 111 & Micronesia, Fed. Sts. & -0.0156 & & & & 0.0738 & & \\
\hline 112 & Moldova & -0.0847 & -0.1689 & & 0.3184 & -0.0059 & 20.8069 & 0.704 \\
\hline 113 & Mongolia & 0.0081 & & & 0.2995 & 0.2154 & 73.6160 & 0.636 \\
\hline 114 & Morocco & 0.0061 & 0.0261 & 0.0596 & -0.6060 & 0.0539 & 3.9532 & 0.569 \\
\hline 115 & Mozambique & 0.0441 & 0.1139 & 0.0541 & 0.2851 & 0.1674 & 32.6771 & 0.313 \\
\hline 116 & Myanmar & 0.0473 & 0.0598 & -0.0859 & 0.0746 & -0.0178 & 25.1062 & \\
\hline 117 & Namibia & 0.0167 & 0.0718 & 0.0585 & & 0.3075 & 10.0611 & 0.629 \\
\hline 118 & Nepal & 0.0233 & 0.0593 & 0.0799 & 0.0951 & 0.0806 & 8.9030 & 0.453 \\
\hline
\end{tabular}




\begin{tabular}{|c|c|c|c|c|c|c|c|c|}
\hline & Appendix 2:Values of the 7 Inc & tors of & conom & nce & $\mathrm{Cr}_{\mathrm{s}}$ & is During & s(conte & \\
\hline No. & Countries & & & sponential Trend & Rates du & uring 1990s & for & \\
\hline & & GDP pc & GCF & $\begin{array}{c}\text { Imports of } \\
\text { Goods \& Serv. }\end{array}$ & FDI & \begin{tabular}{|c|} 
Forex \\
Reserves
\end{tabular} & $\begin{array}{l}\text { Average } \\
\text { Infl. Rate }\end{array}$ & $\begin{array}{c}\text { HDI } \\
(1995)\end{array}$ \\
\hline 119 & Netherlands & 0.0231 & 0.0324 & 0.0531 & 0.2679 & -0.0757 & 2.4517 & 0.922 \\
\hline 120 & Netherlands Antilles & & & & -0.3079 & 0.0294 & 2.6202 & \\
\hline 121 & New Caledonia & -0.0099 & & & & & & \\
\hline 122 & New Zealand & 0.0194 & 0.0774 & 0.0749 & 0.0099 & 0.0405 & 1.7520 & 0.902 \\
\hline 123 & Nicaragua & 0.0106 & 0.1192 & 0.1053 & 0.3554 & 0.2097 & 339.1007 & 0.615 \\
\hline 124 & Niger & -0.0070 & 0.0553 & -0.0086 & 0.0893 & -0.2264 & 4.6485 & 0.262 \\
\hline 125 & Nigeria & -0.0048 & 0.0586 & 0.0482 & 0.0182 & 0.0127 & 30.5977 & 0.448 \\
\hline 126 & Norway & 0.0302 & 0.0569 & 0.0555 & 0.2343 & 0.0547 & 2.3404 & 0.925 \\
\hline 127 & Oman & 0.0024 & & 0.0459 & -0.1756 & 0.0536 & 0.3504 & \\
\hline 128 & Pakistan & 0.0099 & 0.0134 & 0.0189 & 0.0515 & 0.0543 & 9.2472 & 0.473 \\
\hline 129 & Panama & 0.0186 & 0.0963 & 0.0401 & 0.2442 & 0.0707 & 1.1682 & 0.770 \\
\hline 130 & Papua New Guinea & 0.0038 & 0.0015 & 0.0260 & 0.0465 & 0.0350 & 9.6076 & 0.519 \\
\hline 131 & Paraguay & -0.0050 & -0.0015 & 0.0125 & 0.0427 & 0.0225 & 13.5653 & 0.735 \\
\hline 132 & Peru & 0.0295 & 0.0686 & 0.0789 & 0.1444 & 0.1586 & 60.1079 & 0.730 \\
\hline 133 & Philippines & 0.0136 & 0.0374 & 0.0744 & 0.1249 & 0.1536 & 8.6004 & 0.733 \\
\hline 134 & Poland & 0.0506 & 0.1252 & 0.1450 & 0.3483 & 0.2749 & 28.4287 & 0.808 \\
\hline 135 & Portugal & 0.0262 & 0.0549 & 0.0727 & 0.0649 & -0.0663 & 4.9396 & 0.855 \\
\hline 136 & Puerto Rico & 0.0190 & & & & & & \\
\hline 137 & Qatar & & & 0.0666 & & 0.0691 & 2.4808 & \\
\hline 138 & Romania & 0.0034 & -0.0388 & 0.0835 & 0.4008 & 0.1840 & 121.0157 & 0.772 \\
\hline 139 & Russian Federation & -0.0392 & -0.1932 & -0.0379 & 0.1944 & 0.1495 & 197.0376 & 0.779 \\
\hline 140 & Rwanda & -0.0126 & 0.0438 & 0.0247 & 0.2695 & 0.1467 & 8.5853 & 0.335 \\
\hline 141 & Samoa & 0.0235 & & 0.0868 & -0.0552 & 0.0178 & 3.3791 & 0.689 \\
\hline 142 & Sao Tome and Principe & -0.0069 & -0.0026 & -0.0183 & & 0.2014 & & \\
\hline 143 & Saudi Arabia & -0.0154 & 0.0016 & -0.0489 & & 0.1121 & 0.9774 & 0.737 \\
\hline 144 & Senegal & 0.0126 & 0.0576 & 0.0248 & 0.2400 & 0.5500 & 4.4753 & 0.400 \\
\hline 145 & Seychelles & 0.0085 & 0.0719 & 0.1239 & 0.1780 & 0.0108 & 2.2870 & \\
\hline 146 & Sierra Leone & -0.0656 & -0.3083 & -0.0681 & -0.4605 & 0.1382 & 34.7455 & \\
\hline 147 & Singapore & 0.0445 & 0.0714 & & 0.0824 & 0.0981 & 1.7296 & 0.857 \\
\hline 148 & Slovak Republic & 0.0317 & 0.0999 & 0.1113 & 0.2333 & 0.2231 & 9.2172 & 0.817 \\
\hline 149 & Slovenia & 0.0363 & 0.1146 & 0.0734 & 0.0888 & 0.3141 & 13.6422 & 0.852 \\
\hline 150 & Solomon Islands & -0.0153 & & & -0.0099 & 0.1560 & 10.9252 & \\
\hline 151 & Somalia & & & & -0.3466 & & & \\
\hline 152 & South Africa & 0.0030 & 0.0320 & 0.0703 & 0.1003 & 0.2149 & 8.9899 & 0.724 \\
\hline 153 & Spain & 0.0251 & 0.0336 & 0.0894 & 0.0645 & -0.0265 & 3.8929 & 0.895 \\
\hline 154 & Sri Lanka & 0.0387 & 0.0615 & 0.0813 & 0.1068 & 0.0590 & 9.7181 & 0.719 \\
\hline 155 & St. Kitts and Nevis & 0.0467 & 0.0460 & 0.0457 & 0.1800 & 0.1038 & 3.5251 & \\
\hline 156 & St. Lucia & 0.0076 & 0.0246 & 0.0018 & 0.0519 & 0.0500 & 3.2908 & \\
\hline 157 & St. Vincent and the Grenadines & 0.0275 & 0.0511 & 0.0301 & 0.1640 & 0.0712 & 2.4217 & \\
\hline 158 & Sudan & 0.0571 & & & 1.5106 & 0.3072 & 82.1034 & 0.462 \\
\hline 159 & Suriname & 0.0307 & & 0.1085 & & 0.3345 & 104.6147 & \\
\hline 160 & Swaziland & 0.0023 & 0.0209 & 0.0268 & -0.2400 & 0.0616 & 9.4532 & 0.620 \\
\hline 161 & Sweden & 0.0195 & 0.0324 & 0.0678 & 0.2996 & -0.0467 & 2.3303 & 0.925 \\
\hline 162 & Switzerland & 0.0043 & 0.0154 & 0.0467 & 0.2734 & 0.0221 & 1.9597 & 0.914 \\
\hline 163 & Syrian Arab Republic & 0.0240 & 0.0315 & 0.0037 & -0.0680 & & 6.3505 & 0.665 \\
\hline 164 & Tajikistan & -0.1109 & -0.1592 & & 0.1233 & & & 0.669 \\
\hline 165 & Tanzania & 0.0033 & -0.0170 & -0.0346 & 0.3418 & 0.1751 & 20.0971 & 0.427 \\
\hline 166 & Thailand & 0.0267 & -0.0627 & 0.0309 & 0.1360 & 0.0636 & 4.5367 & 0.749 \\
\hline 167 & Togo & 0.0012 & 0.0384 & 0.0307 & 0.1261 & -0.1225 & 7.2101 & 0.476 \\
\hline 168 & Tonga & 0.0212 & & & 0.1246 & -0.0230 & 4.1118 & \\
\hline 169 & Trinidad and Tobago & 0.0264 & 0.1368 & 0.0952 & 0.1602 & 0.2096 & 5.4693 & 0.787 \\
\hline 170 & Tunisia & 0.0305 & 0.0364 & 0.0401 & 0.0795 & 0.1217 & 4.5092 & 0.682 \\
\hline 171 & Turkey & 0.0215 & 0.0426 & 0.1124 & 0.0230 & 0.1928 & 76.7014 & 0.717 \\
\hline 172 & Turkmenistan & -0.0755 & & 0.0064 & 0.0922 & & & \\
\hline 173 & Uganda & 0.0387 & 0.0958 & 0.1403 & 0.5299 & 0.2992 & 12.8222 & 0.404 \\
\hline 174 & Ukraine & -0.0864 & -0.1913 & -0.0050 & 0.1983 & 0.1904 & 876.0535 & 0.745 \\
\hline 175 & United Arab Emirates & -0.0104 & & & & 0.0990 & & \\
\hline
\end{tabular}




\begin{tabular}{|c|c|c|c|c|c|c|c|c|}
\hline \multicolumn{9}{|c|}{ Appendix 2: Values of the 7 Indicators of Economic Performance by Countries During 1990s(concl.) } \\
\hline \multirow[t]{2}{*}{ No. } & \multirow[t]{2}{*}{ Countries } & \multicolumn{7}{|c|}{ Exponential Trend Rates during 1990s for } \\
\hline & & GDP pc & GCF & $\begin{array}{c}\text { Imports of } \\
\text { Goods \& Serv. }\end{array}$ & FDI & $\begin{array}{c}\text { Forex } \\
\text { Reserves }\end{array}$ & $\begin{array}{l}\text { Average } \\
\text { Infl. Rate }\end{array}$ & \begin{tabular}{|c} 
HDI \\
$(1995)$
\end{tabular} \\
\hline 176 & United Kingdom & 0.0241 & 0.0501 & 0.0705 & 0.2550 & -0.0008 & 3.0520 & 0.916 \\
\hline 177 & United States & 0.0243 & 0.0818 & 0.0974 & 0.3080 & -0.0009 & 2.8014 & 0.925 \\
\hline 178 & Uruguay & 0.0238 & 0.0450 & 0.0820 & 0.4198 & 0.1914 & 38.0910 & 0.815 \\
\hline 179 & Uzbekistan & -0.0175 & & -0.0007 & 0.1600 & & & 0.714 \\
\hline 180 & Vanuatu & -0.0143 & 0.0812 & 0.0237 & -0.0309 & -0.0003 & 3.0683 & \\
\hline 181 & Venezuela, RB & -0.0106 & 0.0147 & 0.0416 & 0.2315 & 0.0468 & 33.4913 & 0.766 \\
\hline 182 & Vietnam & 0.0590 & 0.1737 & 0.2688 & 0.1679 & 0.2170 & 3.7115 & 0.649 \\
\hline 183 & West Bank and Gaza & -0.0147 & 0.0370 & 0.0366 & & & & \\
\hline 184 & Yemen, Rep. & 0.0287 & 0.0999 & 0.0783 & & 0.2385 & 30.6111 & 0.439 \\
\hline 185 & Yugoslavia, Fed. Rep. & 0.0039 & & & & & & \\
\hline 186 & Zambia & -0.0196 & 0.0742 & 0.0402 & 0.2167 & -0.1365 & 87.0297 & 0.432 \\
\hline 187 & Zimbabwe & 0.0064 & -0.0476 & 0.0628 & 0.3423 & -0.0187 & 29.8177 & 0.563 \\
\hline
\end{tabular}

Basic Source: (1) World Development Indicators 2002 (on CD ROM)

(2) International Financial Statistics 2003 (online: http://ifs.apdi.net)

(3) Human Development Report 2002 (online: http://hdr.undp.org) 